\title{
Investigation of Surface Segregation in Fe-Cr-Si Alloys by XPS
}

\author{
K. IDCZAK and R. IDCZAK
}

The surface segregation of $\mathrm{Fe}-\mathrm{Cr}-\mathrm{Si}$ alloys was studied using the $\mathrm{X}$-ray photoelectron spectroscopy (XPS). The experiment was performed in two stages, for the as-prepared samples and after oxidation process. Analysis of measured XPS spectra allowed one to characterize the changes in the surface chemical composition during the oxidation and thermal treatment procedures. According to the obtained results, it could be stated that the enhanced anti-corrosion properties of the $\mathrm{Fe}-\mathrm{Cr}$-Si alloys which contain more than 10 at. pet of $\mathrm{Cr}$ and 5 at. pct of $\mathrm{Si}$ in the bulk are mainly connected with the strong surface segregation process of both solutes. In the case of alloys which contain less solutes $\left(\mathrm{Fe}_{0.94} \mathrm{Cr}_{0.03} \mathrm{Si}_{0.03}, \mathrm{Fe}_{0.90} \mathrm{Cr}_{0.05} \mathrm{Si}_{0.05}\right)$, the behavior of $\mathrm{Cr}$ atoms is different during the oxidation process. Chromium does not segregate to the surface, instead it diffuses into deeper parts of the material leaving the surface covered only by silicon and iron oxides. This effect is responsible for much worse corrosion resistance of the $\mathrm{Fe}_{0.94} \mathrm{Cr}_{0.03} \mathrm{Si}_{0.03}$ and $\mathrm{Fe}_{0.90} \mathrm{Cr}_{0.05} \mathrm{Si}_{0.05}$ alloys.

https://doi.org/10.1007/s11661-020-05758-5

(C) The Author(s) 2020

\section{INTRODUCTION}

IRON alloys, including steels, have been intensively studied for years because of their importance as structural materials for the modern industry. Currently, one of the main challenges in this field is related to understand the processes associated with atmospheric and high-temperature corrosion. ${ }^{[1-3]}$ In order to reduce the negative effect of corrosion on the global economy, many researchers are still conducting intensive work to improve the anti-corrosive properties of iron and its alloys with a low content of other elements. The corrosion-resistant properties of these multi-component alloys depend mainly on the surface oxidation mechanism and the ability of alloy surface to form passive films which act as a barrier to additional oxidation reaction in the deeper parts of material. One of the most important physical phenomena which is responsible for the formation of passive films in iron-based alloys is the surface segregation process. ${ }^{[4-9]}$ Due to this process, a very small concentration of solute atoms in the bulk of the material can lead to a very significant coverage of these atoms on a free surface of the alloy.

K. IDCZAK is with the Institute of Experimental Physics, University of Wroclaw, pl. M. Borna 9, 50-204 Wroclaw, Poland. Contact e-mail: kidczak@ifd.uni.wroc.pl R. IDCZAK is with the Institute of Experimental Physics, University of Wroclaw and also with the Institute of Low Temperature and Structure Research, Polish Academy of Science W. Trzebiatowski Institute, ul. Okólna 2, 50-422 Wroclaw, Poland

Manuscript submitted November 6, 2019.

Article published online April 19, 2020
As it was shown previously, ${ }^{[10-16]}$ the addition of $\mathrm{Cr}$ and/or Si atoms to $\alpha$-Fe drastically reduces the oxidation process of iron atoms during exposure to air at high temperature. In particular, the results obtained by the ${ }^{57} \mathrm{Fe}$ transmission Mössbauer spectroscopy (TMS) as well as by the conversion electron Mössbauer spectroscopy (CEMS) for the $\mathrm{Fe}_{0.85} \mathrm{Cr}_{0.10} \mathrm{Si}_{0.05}$ alloy indicate that the high-temperature atmospheric corrosion of this material is almost stopped at $870 \mathrm{~K}$ and $1070 \mathrm{~K} \cdot{ }^{[16]}$ The most plausible explanation of this behavior could be linked to the strong segregation process of $\mathrm{Si}$ and/or $\mathrm{Cr}$ atoms to the alloy surface. However, in a study by Idczak, ${ }^{[16]}$ that suggestion is rather speculative since it requires confirmation by surface-sensitive experimental techniques. An extremely useful tool for this purpose is the X-ray photoelectron spectroscopy (XPS). This experimental technique collects data from a surface layer of a few nanometers and provides detailed information about atomic concentration of selected elements as well as types of atomic bonds which are present on the surface of studied material. ${ }^{[17]}$ Moreover, the XPS experiments which were performed for $\mathrm{Fe}-\mathrm{Cr}{ }^{[4,}$ ${ }^{14]}$ and $\mathrm{Fe}-\mathrm{Si}{ }^{[7,15]}$ systems gave clear evidence that the enhanced anti-corrosion behavior of these binary alloys is connected with the surface segregation of $\mathrm{Cr}$ and $\mathrm{Si}$ atoms. Taking the above into account, this work is mainly focused on determination of the influence of the surface segregation process on the corrosion resistance properties of ternary $\mathrm{Fe}-\mathrm{Cr}-\mathrm{Si}$ alloys. Four polycrystalline $\mathrm{Fe}-\mathrm{Cr}$-Si alloys were investigated by XPS in order to estimate the changes in surface chemical composition caused by oxidative annealing in air at high temperature 
as well as by rapid thermal annealing at various temperatures in vacuum. An insight into corrosion properties of the $\mathrm{Fe}-\mathrm{Cr}-\mathrm{Si}$ alloy is presented in correlation with recently obtained Mössbauer data. ${ }^{[16]}$

\section{EXPERIMENTAL}

The samples of $\mathrm{Fe}_{0.94} \mathrm{Cr}_{0.03} \mathrm{Si}_{0.03}, \mathrm{Fe}_{0.90} \mathrm{Cr}_{0.05} \mathrm{Si}_{0.05}$, $\mathrm{Fe}_{0.85} \mathrm{Cr}_{0.10} \mathrm{Si}_{0.05}$, and $\mathrm{Fe}_{0.80} \mathrm{Cr}_{0.15} \mathrm{Si}_{0.05}$ alloys were prepared in an arc furnace. Appropriate amounts of the 99.98 pct pure iron, 99.995 pct pure chromium, and 99.95 pct pure silicon were melted in a water-cooled copper crucible under argon atmosphere and quickly cooled to room temperature. Solidified alloys were remelted two times to ensure homogeneity. The weight losses during the melting process were below 0.2 pct of the original weight, so it could be assumed that the chemical composition of the obtained ingots is close to nominal ones. In the next step, the resulting ingots were cold-rolled to the final thickness of about $0.10 \mathrm{~mm}$. Finally, the foils were annealed in the vacuum at $1270 \mathrm{~K}$ for 2 hours. The base pressure during the annealing procedure was lower than $10^{-4} \mathrm{~Pa}$. To obtain homogeneous and defect free samples, ${ }^{[18]}$ after the annealing process, the foils were slowly cooled to room temperature during 6 hours. After that preparation, the samples were divided into two groups. The first were alloys annealed only in vacuum (named "as prepared") and the second were additionally exposed to air at $870 \mathrm{~K}$ for 2 hours (named "oxidized"). During exposure to air, the ambient humidity was monitored using hair hygrometer and it was in the range from 45 pct $\mathrm{RH}$ to 65 pet RH.

The quality of prepared samples was checked by TMS. The obtained ${ }^{57} \mathrm{Fe}$ Mössbauer spectra were similar to those presented in Idczak's work ${ }^{[16]}$ indicating that all prepared $\mathrm{Fe}-\mathrm{Cr}-\mathrm{Si}$ alloys were in a single phase with body-centered cubic (bcc) structure. This finding is in agreement with $\mathrm{Fe}-\mathrm{Cr}-\mathrm{Si}$ phase diagrams presented in the work by Cui and Jung. ${ }^{[19]}$

All samples were placed in the ultrahigh-vacuum (UHV) apparatus, with a pressure about $4 \times 10^{-8} \mathrm{~Pa}$, equipped with the XPS analyzer (Phoibos 150) with $\mathrm{Mg}$ $\mathrm{K} \alpha$ and $\mathrm{Al} \mathrm{K} \alpha \mathrm{X}$-ray sources. The measurements were performed in conditions similar to those described in Reference 11. The highest temperature at which the samples were annealed in UHV was $1300 \mathrm{~K}$. According to the $\mathrm{Fe}-\mathrm{Cr}-\mathrm{Si}$ phase diagrams, ${ }^{[19]}$ all studied alloys are stable in the bcc structure up to $1300 \mathrm{~K}$. Therefore, it is plausible to assume that any potential changes in the surface chemical composition which may occur during annealing in UHV cannot be induced by structural phase transitions or formation of new intermetallic phases in the bulk of studied alloys.

Obtained spectra were analyzed using the CasaXPS program. The background of spectra was subtracted using a software based on Shirley method. Fitting method was the Gaussian-Lorentzian (GL(30 pct)). For Fe $2 p$ envelope analysis, the Gupta-Sen multiplet peaks (GS) fitting method was used. ${ }^{[20]}$

\section{RESULTS}

The XPS technique was used to study the chemical composition and surface atomic concentrations of selected elements. The surface atomic concentration $c_{i}$ of selected elements were estimated according to the following formula:

$$
c_{i}=\frac{I_{i} / \sigma_{i} \cdot \lambda_{i}}{\sum I_{j} / \sigma_{j} \cdot \lambda_{j}} \times 100 \mathrm{pct},
$$

where $I_{i}$ is a selected XPS peak intensity (Fe $2 \mathrm{p}_{3 / 2}, \mathrm{Cr}$ $2 \mathrm{p}_{3 / 2}$, Si $2 \mathrm{p}, \mathrm{O} 1 \mathrm{~s}$, and $\mathrm{C} 1 \mathrm{~s}$ ), $\sigma$ is a photoionization cross section for selected element (Scofield parameter), ${ }^{[21]}$ and $\lambda$ is a inelastic mean free path of electrons with a certain kinetic energy related to the selected XPS core-level line. ${ }^{[2]}$ The presented $c_{i}$ values have an uncertainty of less than 2 pct.

\section{A. $\mathrm{Fe}_{0.94} \mathrm{Cr}_{0.03} \mathrm{Si}_{0.03}$ Alloy}

Figure 1 presents the surface atomic concentration of selected elements obtained for the as-prepared and oxidized $\mathrm{Fe}_{0.94} \mathrm{Cr}_{0.03} \mathrm{Si}_{0.03}$ samples after annealing at various temperatures. Figure 2 presents the selected XPS spectra for the same samples after final annealing at $1300 \mathrm{~K}$ in $\mathrm{UHV}$.
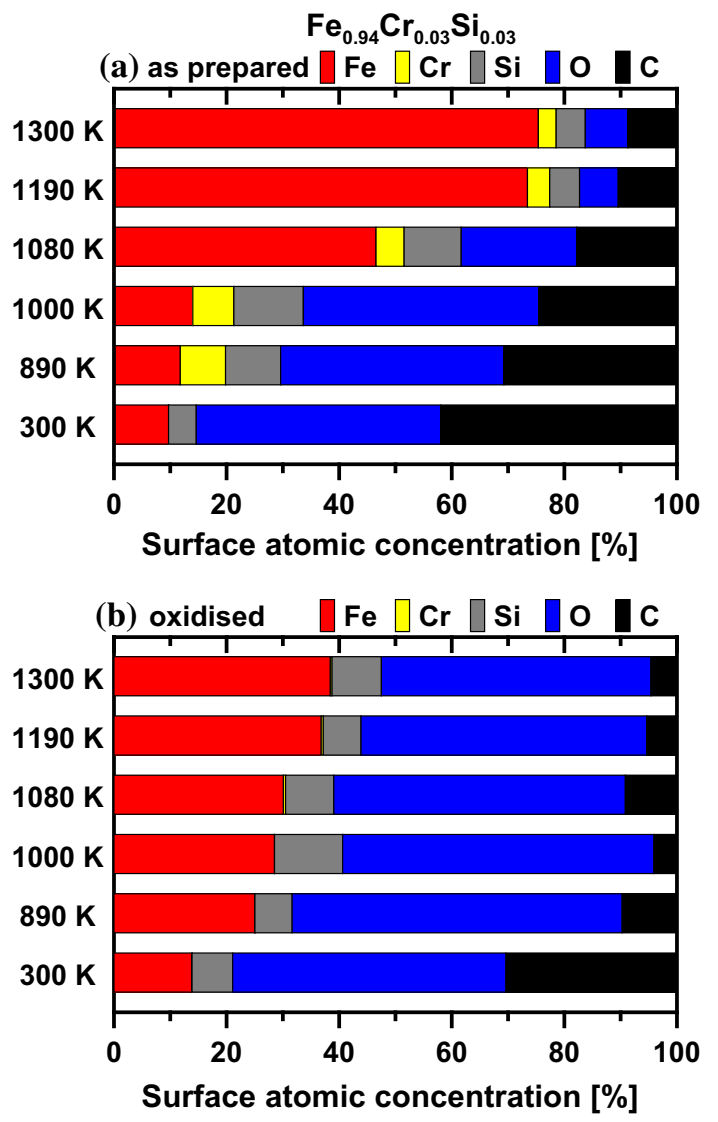

Fig. 1-(Color online) The surface atomic concentrations of selected elements for the as-prepared $(a)$ and oxidized $(b) \mathrm{Fe}_{0.94} \mathrm{Cr}_{0.03} \mathrm{Si}_{0.03}$ samples after annealing at various temperatures. 


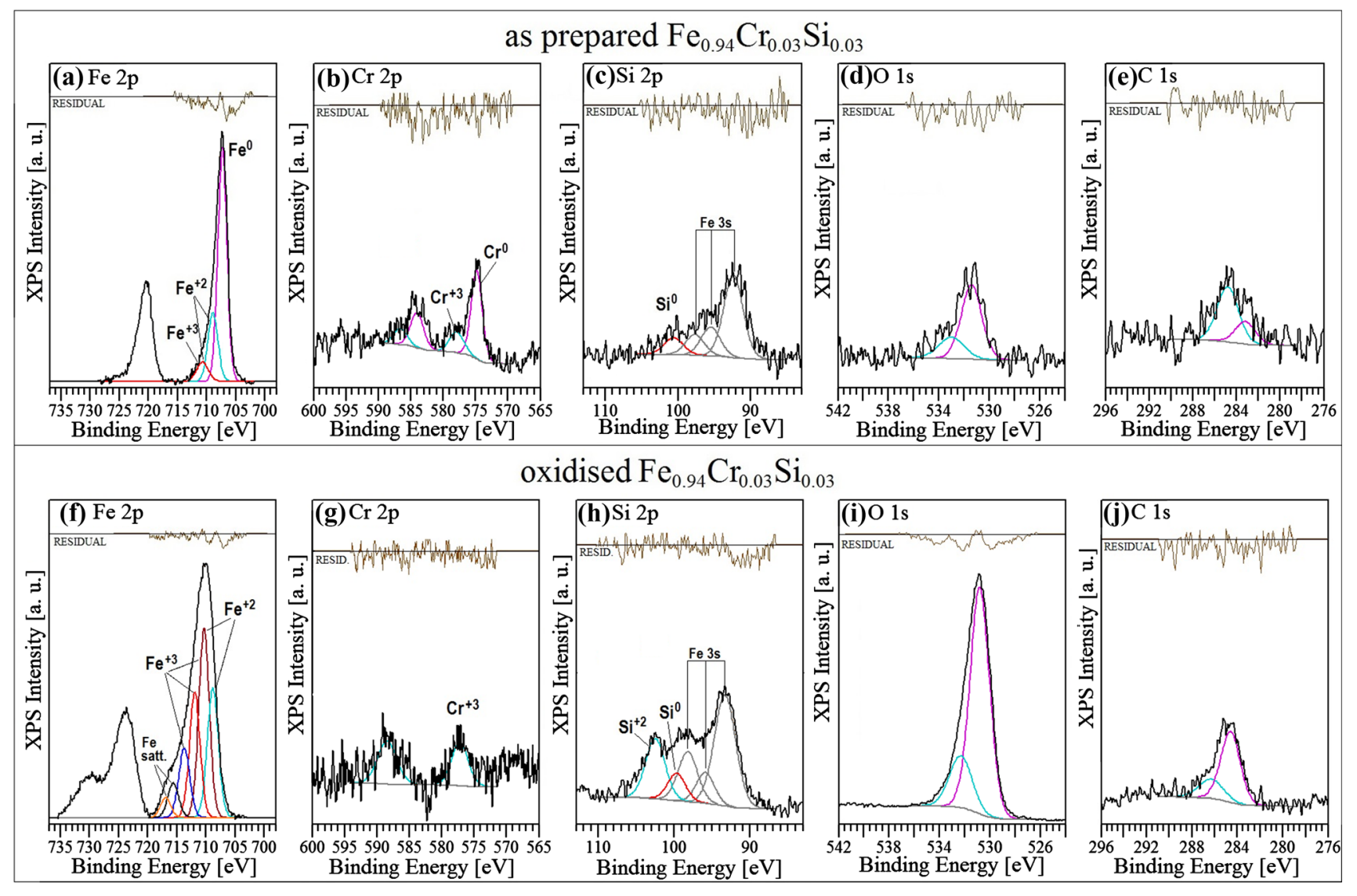

Fig. 2-(Color online) The selected XPS spectra ( $\mathrm{Fe} \mathrm{2p,} \mathrm{Cr} \mathrm{2p,} \mathrm{Si} \mathrm{2p,} \mathrm{O} \mathrm{1s,} \mathrm{and} \mathrm{C} \mathrm{1s)} \mathrm{for} \mathrm{Fe}_{0.94} \mathrm{Cr}_{0.03} \mathrm{Si}_{0.03}$ alloys: $(a)$ to (e) the as-prepared sample after annealing in UHV at $1300 \mathrm{~K} ;(f)$ to $(j)$ the oxidized sample after annealing in UHV at $1300 \mathrm{~K}$.

In the case of the as-prepared sample, the measurements performed just after inserting into the vacuum chamber reveal that the surface is heavily contaminated by $\mathrm{O}$ and $\mathrm{C}$ atoms (see Figure 1(a)-300 K). This result is quite obvious and reflects the fact that the sample before the measurements had a direct contact with air. The determined total concentration of $\mathrm{O}$ and $\mathrm{C}$ atoms is 85.4 pct, while the concentrations of $\mathrm{Fe}, \mathrm{Si}$, and $\mathrm{Cr}$ are 9.7, 4.9, and 0 pet (Cr 2p XPS spectrum is not detected), respectively.

After annealing the as-prepared sample at higher temperatures, the oxygen and carbon contribution decreases gradually (see Figure 1(a)). After the last annealing at $1300 \mathrm{~K}$, the surface region contains about 15 pct of $\mathrm{O}$ and $\mathrm{C}$ atoms. Desorption of contaminants during the heat treatment induces increase of the $\mathrm{Fe}$ content which grows systematically from 9.7 pct (RT) to 75 pct $(1280 \mathrm{~K})$. At the same time, changes of the $\mathrm{Cr}$ and $\mathrm{Si}$ contents are more complicated. Initially, at low temperatures, the concentration of both solutes increases, while at $1080 \mathrm{~K}$ and above, it decreases. That interesting result will be discussed in a later section in more detail. Nevertheless, it should be noted that the estimated $c_{\mathrm{Si}} / c_{\mathrm{Fe}}$ and $c_{\mathrm{Cr}} / c_{\mathrm{Fe}}$ ratios are higher (except $c_{\mathrm{Cr}} / c_{\mathrm{Fe}}$ for $300 \mathrm{~K}$ ) than the corresponding ratios calculated from the sample bulk chemical composition $\left(c_{\mathrm{Si}} / c_{\mathrm{Fe}}^{\text {bulk }}=c_{\mathrm{Cr}} / c_{\mathrm{Fe}}^{\text {bulk }}=3 / 96 \approx 0.03\right)$. It means that the annealing of the as-prepared sample up to $1000 \mathrm{~K}$ causes the segregation process of $\mathrm{Cr}$ and $\mathrm{Si}$ atoms to the surface.

Detailed analysis of XPS spectra measured for the as-prepared $\mathrm{Fe}_{0.94} \mathrm{Cr}_{0.03} \mathrm{Si}_{0.03}$ sample after annealing at $1300 \mathrm{~K}$ (Figures 2(a) to (e)) allows to determine the oxidation state and the chemical composition of the surface region. The Fe $2 p$ core-level line consists of three components, which are presented for the $\mathrm{Fe} 2 \mathrm{p}_{3 / 2}$ peak (Figure 2(a)). The main at the binding energy (BE) of $707.3 \mathrm{eV}$ represents the metallic iron $\left(\mathrm{Fe}^{0}\right),{ }^{[11,23]}$ while the next two at the $\mathrm{BE}$ of 708.9 and $710.7 \mathrm{eV}$ correspond to $\mathrm{Fe}^{2+}$ and $\mathrm{Fe}^{3+}$ species. ${ }^{[1,23]}$ The $\mathrm{Cr} 2 \mathrm{p}$ doublet (Figure 2(b)) consists of two components. The first (and dominant) is the metallic chromium $\left(\mathrm{Cr}^{0}\right)$ with the $\mathrm{BE}$ of $574.8 \mathrm{eV}$ for $2 \mathrm{p}_{3 / 2}$ peak and $584.0 \mathrm{eV}$ for $2 \mathrm{p}_{1 / 2}$ peak, while the second representing $\mathrm{Cr}^{+3}$ is placed at the positions of $577.9 \mathrm{eV}\left(2 \mathrm{p}_{3 / 2}\right)$ and $586.6 \mathrm{eV}\left(2 \mathrm{p}_{1 / 2}\right) .{ }^{[10,24]}$ In the case of $\mathrm{Si} 2 \mathrm{p}$ spectrum (Figure 2(c)), it should be pointed out that in this energy range the Fe 3s envelope occurs too, and thus the detailed deconvolution of this spectrum is necessary to obtain a reliable information about the Si $2 p$ envelope. Proceeding in the same way as in Reference 15, the peak at the position of $99.9 \mathrm{eV}$ could be assigned to $\mathrm{Si}^{0}$ species. ${ }^{[15,25]}$ The $\mathrm{O} 1 \mathrm{1}$ spectrum (Figure 2(d)) exhibits small peak (comparing to the background level) which can be divided into two components: the first one at the $\mathrm{BE}$ of $531.4 \mathrm{eV}$ and the second one at $533.0 \mathrm{eV} .^{[26]}$ The $\mathrm{C}$ 1s signal 
(Figure 2(e)) is also weak. However, its asymmetric shape suggests the presence of two components at 283.2 and $284.8 \mathrm{eV}$.

The results obtained for the oxidized $\mathrm{Fe}_{0.94} \mathrm{Cr}_{0.03} \mathrm{Si}_{0.03}$ alloy (Figure 1(b)) allow to state that the measured surface region is permanently oxidized, even after annealing at very high temperatures. The initial chemical composition of surface region is quite similar to the as-prepared one. However, during annealing only a significant decrease of carbon content is observed (from 30.4 to $4.6 \mathrm{pct}$ ). During thermal treatment, the oxygen contribution first increases (from 48.5 to 58.6 pct at 890 $\mathrm{K})$ and then continuously decreases to 47.9 pct. The concentrations of $\mathrm{Fe}, \mathrm{Cr}$, and $\mathrm{Si}$ atoms gradually increase; nevertheless, the XPS signal from chromium could be observed only in the spectra measured for the sample annealed at temperatures higher than $990 \mathrm{~K}$. Moreover, $\mathrm{c}_{\mathrm{Cr}}$ is always lower than 0.4 pet and the $c_{\mathrm{Cr}}$ $c_{\mathrm{Fe}}$ ratio is about 0.01 . Taking into account that $c_{\mathrm{Cr}} / c_{\mathrm{Fe}}^{\text {bulk }}$ $\approx 0.03$, it is clearly seen that the diffusion of $\mathrm{Cr}$ atoms in the oxidized sample differs from the as-prepared one. At the same time, the silicon atoms segregate from the bulk to the surface region during annealing: at $300 \mathrm{~K}$ the $\mathrm{Si}$ concentration is about $7 \mathrm{pct}$, after annealing at $1000 \mathrm{~K}$ it reaches 12.1 pct $\left(c_{\mathrm{Si}} / c_{\mathrm{Fe}}=0.42\right)$, and after annealing at $1300 \mathrm{~K}$ it decreases to $8.8 \mathrm{pct}\left(c_{\mathrm{Si}} / c_{\mathrm{Fe}}=0.23\right)$.

The presented XPS spectra for oxidized $\mathrm{Fe}_{0.94} \mathrm{Cr}_{0.03} \mathrm{Si}_{0.03}$ alloy after annealing at $1300 \mathrm{~K}$ (see Figures 2(f) to (j)) exhibit broadened peak and shifted to a higher binding energy peak. Fe $2 \mathrm{p}$ core-level line (Figure 2(f)) is deconvoluted into six components (marked for $\mathrm{Fe} 2 \mathrm{p}_{3 / 2}$ peak) with the $\mathrm{BE}$ in the range of 708.8 to $716.9 \mathrm{eV}$, and all these energies correspond to $\mathrm{Fe}^{2+}$ and $\mathrm{Fe}^{3+}$ species. ${ }^{[1,23]}$ The chromium signal (Figure 2(g)) is at the background level; however, the $2 \mathrm{p}$ doublet maxima can be distinguished at the positions around $577.2 \mathrm{eV}\left(2 \mathrm{p}_{3 / 2}\right)$ and $588.3 \mathrm{eV}\left(2 \mathrm{p}_{1 / 2}\right)$, which represent $\mathrm{Cr}^{3+}$ species. ${ }^{[14,26]}$ The $\mathrm{Si} 2 \mathrm{p}$ spectrum is composed of two peaks (Figure 2(h)). The main is at the $\mathrm{BE}$ of $102.5 \mathrm{eV}$ and corresponds to $\mathrm{Fe}_{2} \mathrm{SiO}_{4}$ (fayalite). ${ }^{[6}$,

15] The second at the $\mathrm{BE}$ of $99.7 \mathrm{eV}$ represents $\mathrm{Si}^{0}$ species - the only non-oxidized component. O 1s signal is dominant in the full binding energy range of XPS measurement and consists of two components with maxima at the position of 530.8 and $532.3 \mathrm{eV}$ (Figure 2(i)). The C 1s peak intensity is close to the background; however, two components can be distinguished at the position of 284.6 and $286.3 \mathrm{eV}$ (Figure 2(j)).

\section{B. $\mathrm{Fe}_{0.90} \mathrm{Cr}_{0.05} \mathrm{Si}_{0.05}$ Alloy}

Figure 3 presents the surface atomic concentration of selected elements estimated for the as-prepared and oxidized $\mathrm{Fe}_{0.90} \mathrm{Cr}_{0.05} \mathrm{Si}_{0.05}$ samples after annealing at various temperatures.

The results for as-prepared sample (see. Figure 3(a)) just after inserting into the vacuum chamber are similar to the $\mathrm{Fe}_{0.94} \mathrm{Cr}_{0.03} \mathrm{Si}_{0.03}$ alloy. The estimated surface chemical composition shows that the surface region is heavily contaminated by oxygen and carbon atoms. The total contribution of these two elements is higher than
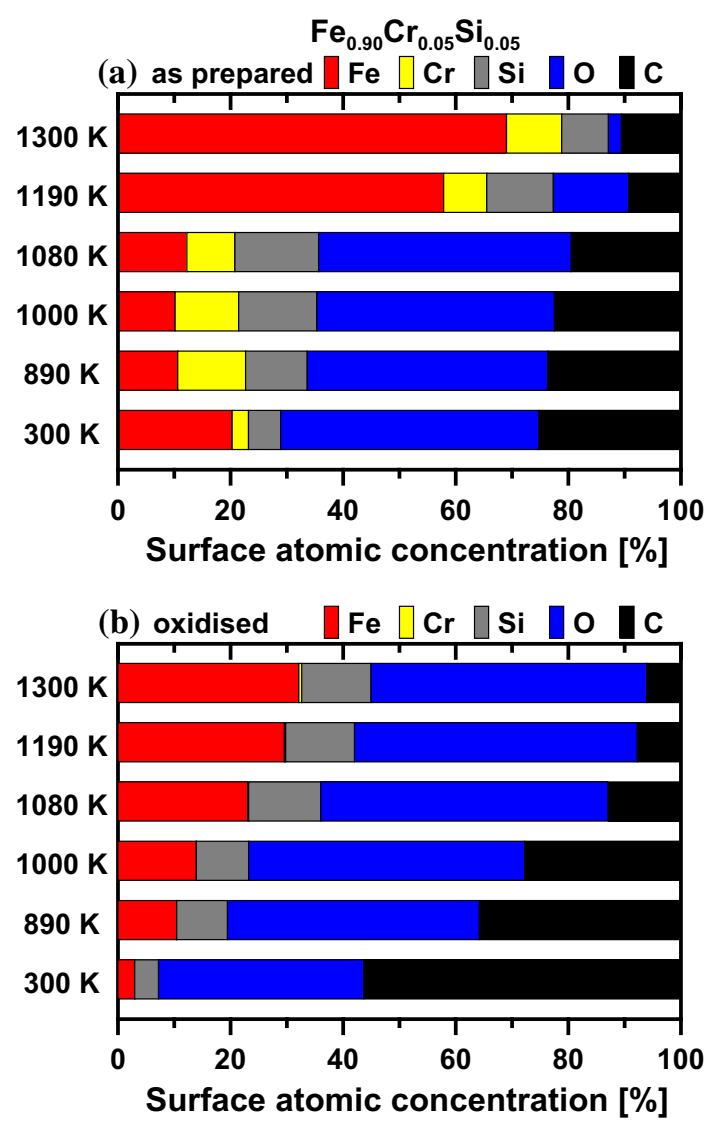

Fig. 3-(Color online) The surface atomic concentrations of selected elements for the as-prepared $(a)$ and oxidized $(b) \mathrm{Fe}_{0.90} \mathrm{Cr}_{0.05} \mathrm{Si}_{0.05}$ samples after annealing at various temperatures.

70 pct. The estimated concentrations of other elements are $\mathrm{Fe}-20.3$ pct, $\mathrm{Si}-5.7$ pct, $\mathrm{Cr}-3.0$ pct. Annealing the sample at $890 \mathrm{~K}$ causes the decrease in Fe contribution to 10.6 pct and increase of $\mathrm{Si}$ and $\mathrm{Cr}$ contribution to 12.0 and 10.9 pct, respectively. Subsequent annealing induces further silicon atoms segregation, while chromium and iron concentrations decrease. Finally, after annealing at $1190 \mathrm{~K}$ and $1300 \mathrm{~K}$, most oxygen and carbon contamination desorbs and the surface region is composed of 69.0 pet $\mathrm{Fe}$ atoms, 9.8 pet $\mathrm{Cr}$ atoms, 8.3 pct $\mathrm{Si}$ atoms, 2.3 pet $\mathrm{O}$ atoms, and 10.6 pet $\mathrm{C}$ atoms. The $c_{\mathrm{Si}} / c_{\mathrm{Fe}}$ ratio is 0.12 and the $c_{\mathrm{Cr}} / c_{\mathrm{Fe}}$ ratio is 0.14 which are about two times higher than $c_{\mathrm{Si}} / c_{\mathrm{Fe}}^{\text {bulk }}=c_{\mathrm{Cr}} /$ $c_{\mathrm{Fe}}^{\text {bulk }} \approx 0.056$. This result clearly points out that silicon and chromium segregate to the surface of $\mathrm{Fe}_{0.90} \mathrm{Cr}_{0.05} \mathrm{Si}_{0.05}$ alloy.

The initial surface chemical composition of oxidized $\mathrm{Fe}_{0.90} \mathrm{Cr}_{0.05} \mathrm{Si}_{0.05}$ alloy is 92.8 pet for $\mathrm{O}$ and $\mathrm{C}, 3.0$ pet for $\mathrm{Fe}, 4.2$ pet for $\mathrm{Si}$, and 0.0 pct for $\mathrm{Cr}$ (see Figure 3(b)). Similarly to the $\mathrm{Fe}_{0.94} \mathrm{Cr}_{0.03} \mathrm{Si}_{0.03}$ sample, a weak chromium signal is detected only in the spectra measured for the sample annealed at temperatures higher than $890 \mathrm{~K}$. Moreover, for the oxidized sample, oxygen is the major component of the surface region and its concentration does not change during annealing. At the same time, a significant decrease of carbon content is observed. After annealing at $1300 \mathrm{~K}$, the surface is 
composed of 32.1 pet Fe atoms, 0.5 pct $\mathrm{Cr}$ atoms, 12.3 pct $\mathrm{Si}$ atoms, 49.0 pet $\mathrm{O}$ atoms, and 6.1 pct $\mathrm{C}$ atoms, which means that the silicon atoms strongly segregate from the bulk to the surface, while the chromium atoms probably diffuse into deeper regions $\left(c_{\mathrm{Si}} / c_{\mathrm{Fe}}\right.$ ratio is 0.38 and $c_{\mathrm{Cr}} / c_{\mathrm{Fe}}$ ratio is 0.02 ).

Figure 4 presents selected XPS spectra with detailed deconvolution after final annealing of the as-prepared and oxidized $\mathrm{Fe}_{0.90} \mathrm{Cr}_{0.05} \mathrm{Si}_{0.05}$ alloys.

In the case of the as-prepared $\mathrm{Fe}_{0.90} \mathrm{Cr}_{0.05} \mathrm{Si}_{0.05}$ alloy (see Figures 4(a) to (e)), after annealing at $1300 \mathrm{~K}$, in the Fe $2 \mathrm{p}$ spectrum four components are distinguished (marked for the $\mathrm{Fe} 2 \mathrm{p}_{3 / 2}$ peak). The main component at the $\mathrm{BE}$ of $707.2 \mathrm{eV}$ represents the metallic iron $\left(\mathrm{Fe}^{0}\right),{ }^{[23]}$ while the next three at the positions of 708.6, 710.1, and $711.8 \mathrm{eV}$ correspond to $\mathrm{Fe}^{2+}$ and $\mathrm{Fe}^{3+}$ species (see Figure 4(a)). ${ }^{[23]}$ The $\mathrm{Cr} 2 \mathrm{p}$ doublet (Figure 4(b)) is composed of two peaks representing $\mathrm{Cr}^{0}$ species (at the $\mathrm{BE}$ of $574.8 \mathrm{eV}$ for $2 \mathrm{p}_{3 / 2}$ ) and $\mathrm{Cr}^{3+}$ species (at the $\mathrm{BE}$ of $576.7 \mathrm{eV}$ for $\left.2 \mathrm{p}_{3 / 2}\right) .{ }^{[10,26]}$ In the case of $\mathrm{Si} 2 \mathrm{p}$ spectrum (Figure 4(c)), after separation of the $\mathrm{Fe} 3 \mathrm{~s}$ signal, the $\mathrm{Si}^{0}$ component is distinguished at the position of $99.9 \mathrm{eV} .{ }^{[15,25]}$ Despite that oxygen and carbon signals are close to the background level, they are presented and analyzed. Similar to the $\mathrm{Fe}_{0.94} \mathrm{Cr}_{0.03} \mathrm{Si}_{0.03}$ alloy, two components for each spectrum are distinguished: 531.8 and $533.2 \mathrm{eV}$ for the $\mathrm{O} 1 \mathrm{~s}$ (Figure 4(d)), and 283.7 and $285.6 \mathrm{eV}$ for the $\mathrm{C} 1 \mathrm{~s}$ (Figure $4(\mathrm{e})) .^{[10,15]}$

Results presented for the oxidized $\mathrm{Fe}_{0.90} \mathrm{Cr}_{0.05} \mathrm{Si}_{0.05}$ alloy after annealing at $1300 \mathrm{~K}$ (Figure 4) are similar to those obtained for the oxidized $\mathrm{Fe}_{0.94} \mathrm{Cr}_{0.03} \mathrm{Si}_{0.03}$ alloy. Deconvolution of $\mathrm{Fe} 2 \mathrm{p}$ and $\mathrm{Cr} 2 \mathrm{p}$ spectra exhibits peaks only at the positions corresponding to oxide compounds. In the case of the $\mathrm{Fe} 2 \mathrm{p}$ core-level line (Figure 4(f)), there are five peaks with the $\mathrm{BE}$ in the range of 709.4 to $716.8 \mathrm{eV}\left(\mathrm{Fe}^{2+}\right.$ and $\mathrm{Fe}^{3+}$ species). The chromium signal (Figure $4(\mathrm{~g})$ ) is at the background level; however, the $2 \mathrm{p}$ doublet (correspond to $\mathrm{Cr}^{3+}$ species) can be distinguished with the maximum at the position around $577.6 \mathrm{eV}\left(2 \mathrm{p}_{3 / 2}\right)$ and $587.3 \mathrm{eV}\left(2 \mathrm{p}_{1 / 2}\right)$. In the case of the $\mathrm{Si} 2 \mathrm{p}$ peak (Figure 4(h)), a well-distinguished component is placed at the $\mathrm{BE}$ of $102.5 \mathrm{eV}$ which corresponds to $\mathrm{Fe}_{2} \mathrm{SiO}_{4}$ (fayalite). However, at the $\mathrm{BE}$ of $99.5 \mathrm{eV}$ there is a component which probably represents both $\mathrm{Si}^{0}$ and $\mathrm{Fe}^{3+}$ species (from the $\mathrm{Fe} 3 \mathrm{~s}$ envelope). ${ }^{[15]}$ As it was mentioned before, the main surface component in measured surface region is oxygen. The presented $\mathrm{O}$ 1s envelope (Figure 4(i)) contains two components, first at the position of $531.1 \mathrm{eV}$ and second at the $\mathrm{BE}$ of $532.5 \mathrm{eV}$. The $\mathrm{C} 1 \mathrm{~s}$ spectrum (Figure 4(j)) is composed of two components (BE of 284.6 and $286.3 \mathrm{eV})$.

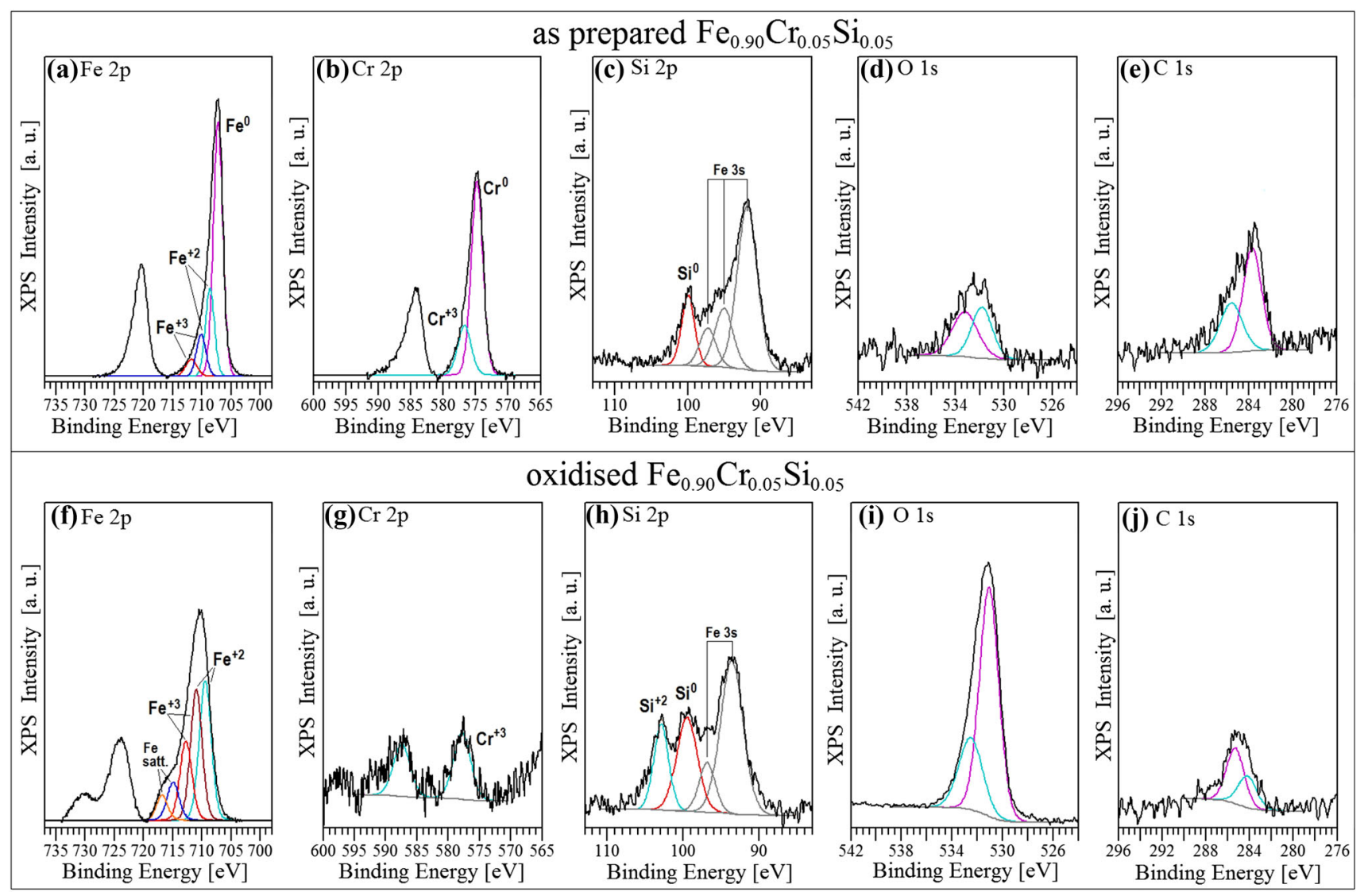

Fig. 4 - (Color online) The selected XPS spectra (Fe 2p, Cr 2p, Si 2p, O 1s, and C 1s) for $\mathrm{Fe}_{0.90} \mathrm{Cr}_{0.05} \mathrm{Si}_{0.05}$ alloys: (a) to (e) the as-prepared sample after annealing in UHV at $1300 \mathrm{~K} ;(f)$ to $(j)$ the oxidized sample after annealing in UHV at $1300 \mathrm{~K}$. 


\section{C. $\mathrm{Fe}_{0.85} \mathrm{Cr}_{0.10} \mathrm{Si}_{0.05}$ Alloy}

Figure 5 presents the surface atomic concentration of selected elements estimated for the as-prepared and oxidized $\mathrm{Fe}_{0.85} \mathrm{Cr}_{0.10} \mathrm{Si}_{0.05}$ samples after annealing at various temperatures.

At RT, in the surface region of the as-prepared $\mathrm{Fe}_{0.85} \mathrm{Cr}_{0.10} \mathrm{Si}_{0.05}$ sample, the initial contributions of iron, chromium, and silicon are 16.5, 7.8, and 6.0 pct, respectively, while the total concentration of oxygen and carbon is about 69.7 pct (Figure $5(\mathrm{a})-300 \mathrm{~K}$ ). The initial $c_{\mathrm{Si}} / c_{\mathrm{Fe}}$ ratio is $0.36\left(c_{\mathrm{Si}} / c_{\mathrm{Fe}}^{\text {bulk }} \approx 0.06\right)$ and $c_{\mathrm{Cr}} / c_{\mathrm{Fe}}$ ratio is $0.47\left(c_{\mathrm{Cr}} / c_{\mathrm{Fe}}^{\text {bulk }} \approx 0.12\right)$. This result implies that during the sample preparation procedure, the surface segregation process already occurred. Annealing the sample leads to changes in the chemical composition (Figure 5(a)), which are similar to those observed for the $\mathrm{Fe}_{0.90} \mathrm{Cr}_{0.05} \mathrm{Si}_{0.05}$ alloys. After the last annealing at 1300 $\mathrm{K}$, the surface is composed of 69.3 pct of iron, 14.4 pct of chromium and 9.2 pct of silicon, while the total concentration of oxygen and carbon is reduced to 7.1 pct. The $c_{\mathrm{Si}} / c_{\mathrm{Fe}}$ ratio is 0.13 and $c_{\mathrm{Cr}} / c_{\mathrm{Fe}}$ ratio is 0.21 . Similar to $\mathrm{Fe}_{0.94} \mathrm{Cr}_{0.03} \mathrm{Si}_{0.03}$ and $\mathrm{Fe}_{0.90} \mathrm{Cr}_{0.05} \mathrm{Si}_{0.05}$ alloys, these two ratios are about two times higher than corresponding $c_{\mathrm{Si}} / c_{\mathrm{Fe}}^{\text {bulk }}$ and $c_{\mathrm{Cr}} / c_{\mathrm{Fe}}^{\text {bulk }}$.

Results obtained for oxidized $\mathrm{Fe}_{0.85} \mathrm{Cr}_{0.10} \mathrm{Si}_{0.05}$ alloy (Figure 5(b)) before and after annealing also imply the occurrence of segregation of silicon and chromium
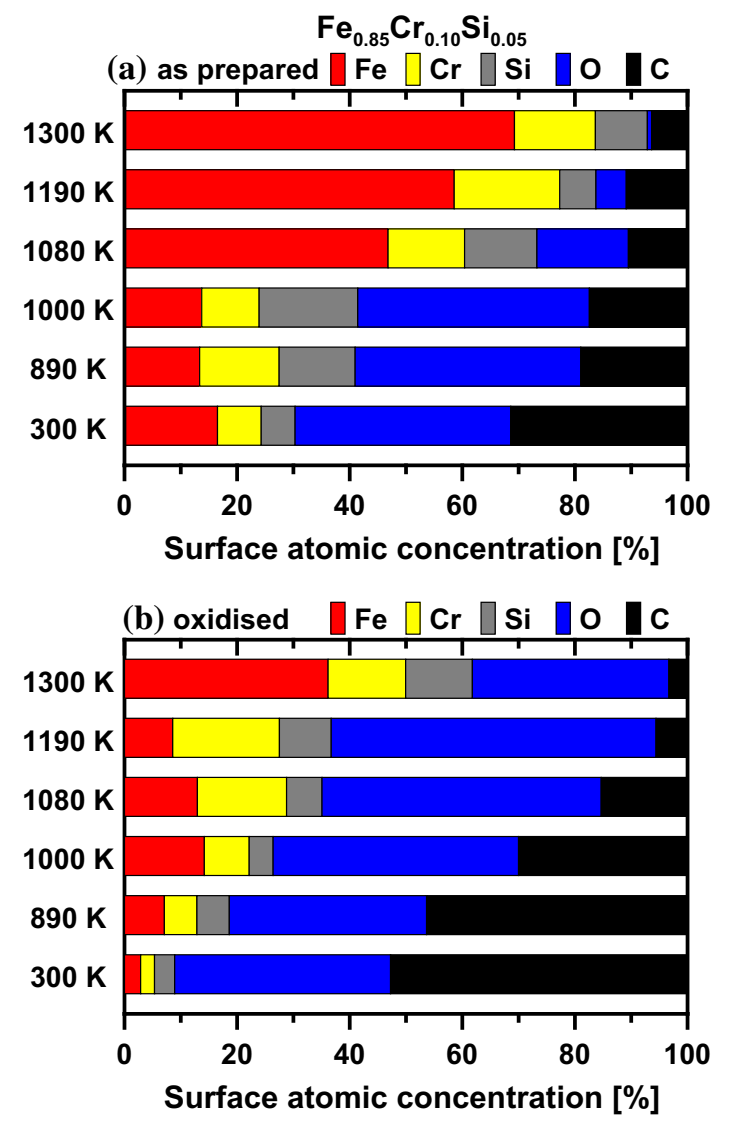

Fig. 5-(Color online) The surface atomic concentrations of selected elements for the as-prepared $(a)$ and oxidized $(b) \mathrm{Fe}_{0.85} \mathrm{Cr}_{0.10} \mathrm{Si}_{0.05}$ samples after annealing at various temperatures. atoms. In this case, despite heavy surface contamination (91.1 pct), $\mathrm{Fe}, \mathrm{Si}$, and $\mathrm{Cr}$ signals are observed already at room temperature. The initial iron contribution is 2.9 pct and it consistently increases to 13.0 pct after annealing at $890 \mathrm{~K}$. After annealing at higher temperatures, it gradually decreases to 8.6 pct $(1190 \mathrm{~K})$ and finally after heating at $1300 \mathrm{~K}$ it reaches 36.2 pct. The initial silicon concentration is 3.6 pct. It increases after first annealing to 5.8 pct and then drops after heating at $980 \mathrm{~K}$ to 4.3 pct. Further annealing causes the increase of the Si contribution - finally it reaches 11.8 pct. In the case of carbon and oxygen concentration, after annealing at $1300 \mathrm{~K}$ in the sample surface region 34.9 pct of $\mathrm{O}$ atoms and 3.3 pct of $\mathrm{C}$ atoms are detected. The most important difference between the oxidized $\mathrm{Fe}_{0.85} \mathrm{Cr}_{0.10} \mathrm{Si}_{0.05}$ sample and the oxidized alloys with the lower content of solutes is connected with the concentration of chromium atoms. In contrast to the oxidized $\mathrm{Fe}_{0.94} \mathrm{Cr}_{0.03} \mathrm{Si}_{0.03}$ and $\mathrm{Fe}_{0.90} \mathrm{Cr}_{0.05} \mathrm{Si}_{0.05}$ alloys where the Cr signal was at the background level, in the oxidized $\mathrm{Fe}_{0.85} \mathrm{Cr}_{0.10} \mathrm{Si}_{0.05}$ sample the initial chromium concentration is 2.5 pct. After annealing at high temperatures, the $\mathrm{Cr}$ content increases reaching 19.0 pct at $1180 \mathrm{~K}$ and 13.8 pct at $1300 \mathrm{~K}$. The $c_{\mathrm{Si}} / c_{\mathrm{Fe}}$ ratio is 0.33 and $c_{\mathrm{Cr}} / c_{\mathrm{Fe}}$ ratio is 0.38 , which are, respectively, five and three times higher than corresponding $c_{\mathrm{Si}} / c_{\mathrm{Fe}}^{\text {bulk }}$ and $c_{\mathrm{Cr}} / c_{\mathrm{Fe}}^{\text {bulk }}$ ratios. According to that it can be state that segregation of $\mathrm{Cr}$ and $\mathrm{Si}$ to the surface region of $\mathrm{Fe}_{0.85} \mathrm{Cr}_{0.10} \mathrm{Si}_{0.05}$ alloy occurs not only during sample preparation but also during heating.

Figure 6 presents selected XPS spectra for the as-prepared and oxidized $\mathrm{Fe}_{0.85} \mathrm{Cr}_{0.10} \mathrm{Si}_{0.05}$ samples after annealing in UHV at $1300 \mathrm{~K}$.

The spectra for the as-prepared $\mathrm{Fe}_{0.85} \mathrm{Cr}_{0.10} \mathrm{Si}_{0.05}$ sample present peaks/components similar to the alloys described before $\left(\mathrm{Fe}_{0.94} \mathrm{Cr}_{0.03} \mathrm{Si}_{0.03}\right.$ and $\mathrm{Fe}_{0.90} \mathrm{Cr}_{0.05} \mathrm{Si}_{0.05}$ ). The Fe $2 \mathrm{p}$ doublet (Figure 6(a)) is composed of four components, from which the most dominant is the $\mathrm{Fe}^{0}$ doublet at $\mathrm{BE}$ of $707.3 \mathrm{eV}\left(\mathrm{Fe} 2 \mathrm{p}_{3 / 2}\right)$ and $720.4 \mathrm{eV} \quad\left(\mathrm{Fe} 2 \mathrm{p}_{1 / 2}\right)$. The $\mathrm{Cr} 2 \mathrm{p}$ doublet (Figure 6(b)) is deconvoluted into two components: the first at positions of $574.8 \mathrm{eV}\left(\mathrm{Cr} 2 \mathrm{p}_{3 / 2}\right)$ and $584.1 \mathrm{eV}$ $\left(\mathrm{Cr} 2 \mathrm{p}_{1 / 2}\right)$ corresponds to $\mathrm{Cr}^{0}$ and the second with maxima placed at 576.7 and $586.0 \mathrm{eV}$ represents $\mathrm{Cr}^{3+}$ species. The Si $2 p$ peak (Figure 6(c)) is at the BE of $100.0 \mathrm{eV}\left(\mathrm{Si}^{0}\right)$. The signal from $\mathrm{O}$ is close to the background level and due to that the position of maximum of the $\mathrm{O}$ 1s peak cannot be determined (Figure 6(d)). In the C 1s spectrum (Figure 6(e)), two components with $\mathrm{BE}$ of 283.6 and $285.9 \mathrm{eV}$ are distinguished.

The results obtained for the oxidized $\mathrm{Fe}_{0.85} \mathrm{Cr}_{0.10} \mathrm{Si}_{0.05}$ sample reveal that after annealing at $1300 \mathrm{~K}$ the surface is composed not only of $\mathrm{Fe}, \mathrm{Cr}$, and $\mathrm{Si}$ oxides. Signals from pure elements are also detected. The $\mathrm{Fe} 2 \mathrm{p}$ spectrum (Figure 6(f)) consists of four components. The main, placed at the position of $707.3 \mathrm{eV}$, corresponds to the $\mathrm{Fe}^{0}$ species, and the rest (at the $\mathrm{BE}$ of $708.8,710.6,712.3 \mathrm{eV}$ ) represent $\mathrm{Fe}^{2+}$ and $\mathrm{Fe}^{3+}$ species. A line shape of chromium signal is different from those presented before for the oxidized $\mathrm{Fe}_{0.94} \mathrm{Cr}_{0.03} \mathrm{Si}_{0.03}$ and $\mathrm{Fe}_{0.90} \mathrm{Cr}_{0.05} \mathrm{Si}_{0.05}$ alloys. The detailed deconvolution of 


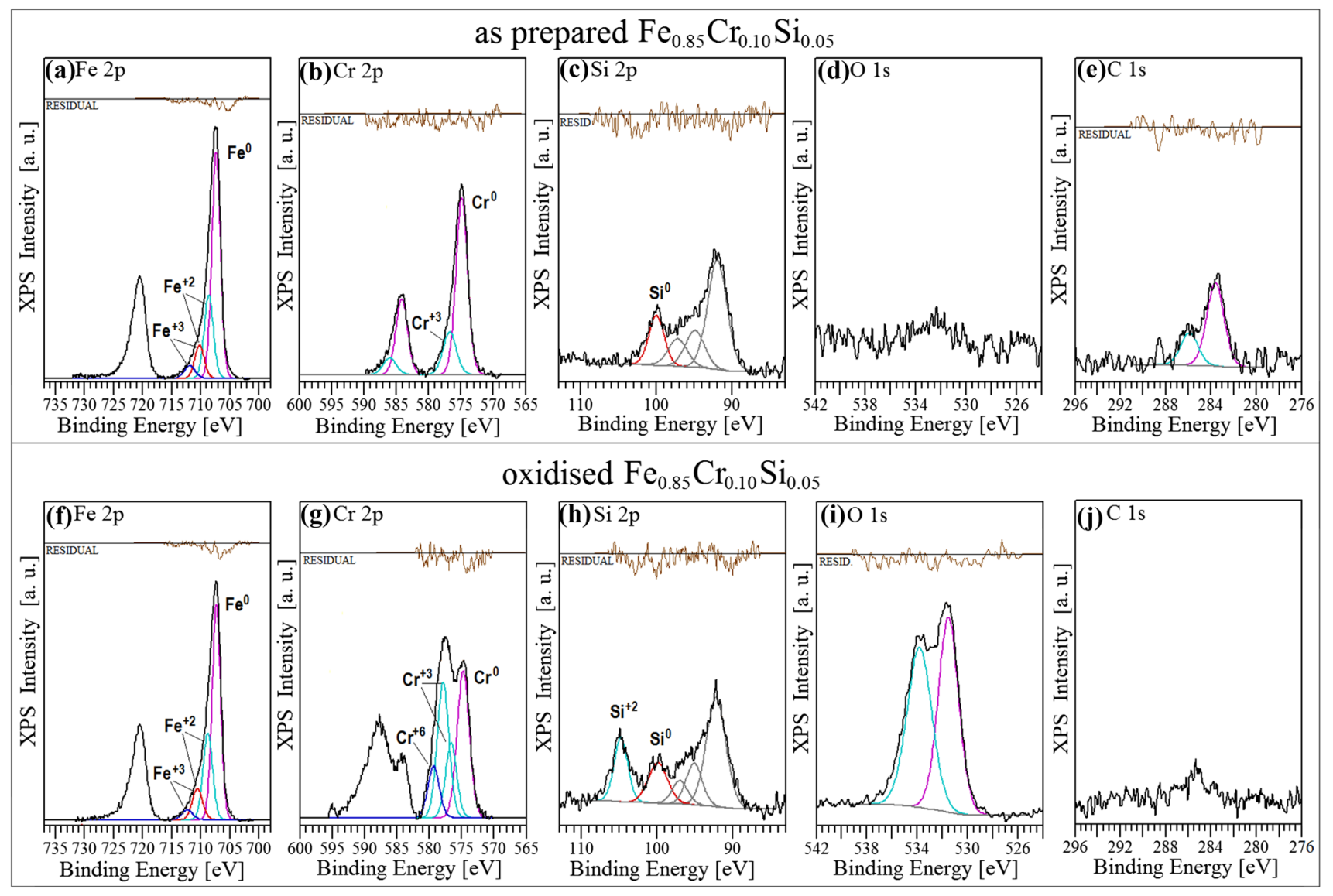

Fig. 6 - (Color online) The selected XPS spectra ( $\mathrm{Fe} \mathrm{2p,} \mathrm{Cr} \mathrm{2p,} \mathrm{Si} \mathrm{2p,} \mathrm{O} \mathrm{1s,} \mathrm{and} \mathrm{C} \mathrm{1s)} \mathrm{for} \mathrm{Fe}_{0.85} \mathrm{Cr}_{0.10} \mathrm{Si}_{0.05}$ alloys: (a) to (e) the as-prepared sample after annealing in UHV at $1300 \mathrm{~K} ;(f)$ to $(j)$ the oxidized sample after annealing in UHV at $1300 \mathrm{~K}$.

Cr $2 \mathrm{p}_{3 / 2}$ peak (Figure $6(\mathrm{~g})$ ) reveals four components. The first, placed at the lowest $\mathrm{BE}$ of $574.7 \mathrm{eV}$, is related to the $\mathrm{Cr}^{0}$, the next two at $\mathrm{BE}$ of 576.6 and $577.8 \mathrm{eV}$ correspond to $\mathrm{Cr}^{3+}$, and the last one, which is the maximum placed at $579.3 \mathrm{eV}$, represents $\mathrm{Cr}^{6+} \cdot{ }^{614,26]} \mathrm{In}$ the case of the $\mathrm{Si} 2 \mathrm{p}$ spectrum (Figure 6(h)), two components at $\mathrm{BE}$ of 99.9 and $104.8 \mathrm{eV}$, related to $\mathrm{Si}^{0}$ and $\mathrm{Si}^{4+}\left(\mathrm{SiO}_{2}\right)$, are distinguished. Here, it is worth noting that the signal from $\mathrm{SiO}_{2}$ appears for the first time in this work. All Si $2 p$ spectra, analyzed before, contains only components connected with $\mathrm{Si}^{0}$ or/and $\mathrm{Fe}_{2} \mathrm{SiO}_{4}$ (fayalite). In the $\mathrm{O}$ 1s spectrum, two local maxima are visible. This indicates the presence at least of two peaks (at BE of 531.5 and $533.8 \mathrm{eV}$ ). The position of maximum of the $\mathrm{C}$ 1s peak (Figure 6(j)) cannot be determined due to the low signal/background intensity ratio.

\section{D. $\mathrm{Fe}_{0.80} \mathrm{Cr}_{0.15} \mathrm{Si}_{0.05}$ Alloy}

Figure 7 presents the surface atomic concentration for the as-prepared and oxidized $\mathrm{Fe}_{0.80} \mathrm{Cr}_{0.15} \mathrm{Si}_{0.05}$ alloys after annealing at various temperatures. Figure 8 presents the selected XPS spectra for the same samples after annealing in UHV at $1300 \mathrm{~K}$.

In the case of the as-prepared sample (Figure 7(a)), the measurements performed at RT and after subsequent annealing up to $1300 \mathrm{~K}$ present a standard cleaning process of $\mathrm{C}$ and $\mathrm{O}$ contaminations and the surface segregation of $\mathrm{Cr}$ and $\mathrm{Si}$ solutes. The changes of carbon and oxygen concentrations during sample annealing are similar to those observed previously for all the as-prepared samples. After annealing at $1300 \mathrm{~K}$, the contribution of $\mathrm{C}$ atoms is $4.6 \mathrm{pct}$, while the $\mathrm{O}$ contribution is 2.3 pct. The $\mathrm{Fe}$ contribution consequently increases from $9.2 \mathrm{pct}(\mathrm{RT})$ to $61.7 \mathrm{pct}$ (for 1300 $\mathrm{K})$. The surface atomic concentration of chromium for the sample at RT is 7.8 pct, after annealing at $890 \mathrm{~K}$ it is over twice higher, but after annealing at $1000 \mathrm{~K}$ it decreases to 15.1 pct. Further sample heating causes increase in the $\mathrm{Cr}$ contribution up to 25.0 pct. Finally, after annealing at $1300 \mathrm{~K}$, the $\mathrm{Cr}$ contribution is 23.8 pct. The silicon concentration firstly increases from 2.9 to 12.4 pct and $16.2 \mathrm{pct}$ after annealing at $890 \mathrm{~K}$ and $1000 \mathrm{~K}$, respectively. Further heating at higher temperatures causes decrease inthe Si content, which reaches $7.6 \mathrm{pct}$ after last annealing at $1300 \mathrm{~K}$. The final $c_{\mathrm{Si}} / c_{\mathrm{Fe}}$ and $c_{\mathrm{Cr}} / c_{\mathrm{Fe}}$ ratios are 0.12 and 0.39 , respectively. Similar to other as-obtained alloys, these two ratios are about two times higher than $c_{\mathrm{Si}} / c_{\mathrm{Fe}}^{\text {bulk }} \approx 0.06$ and $c_{\mathrm{Cr}} / c_{\mathrm{Fe}}^{\text {bulk }} \approx$ 0.19 .

The selected XPS spectra for the as-prepared $\mathrm{Fe}_{0.80} \mathrm{Cr}_{0.15} \mathrm{Si}_{0.05}$ alloy after annealing at $1300 \mathrm{~K}$ (Figures $8(\mathrm{a})$ to (e)) show the Fe $2 \mathrm{p}$ core-level line 

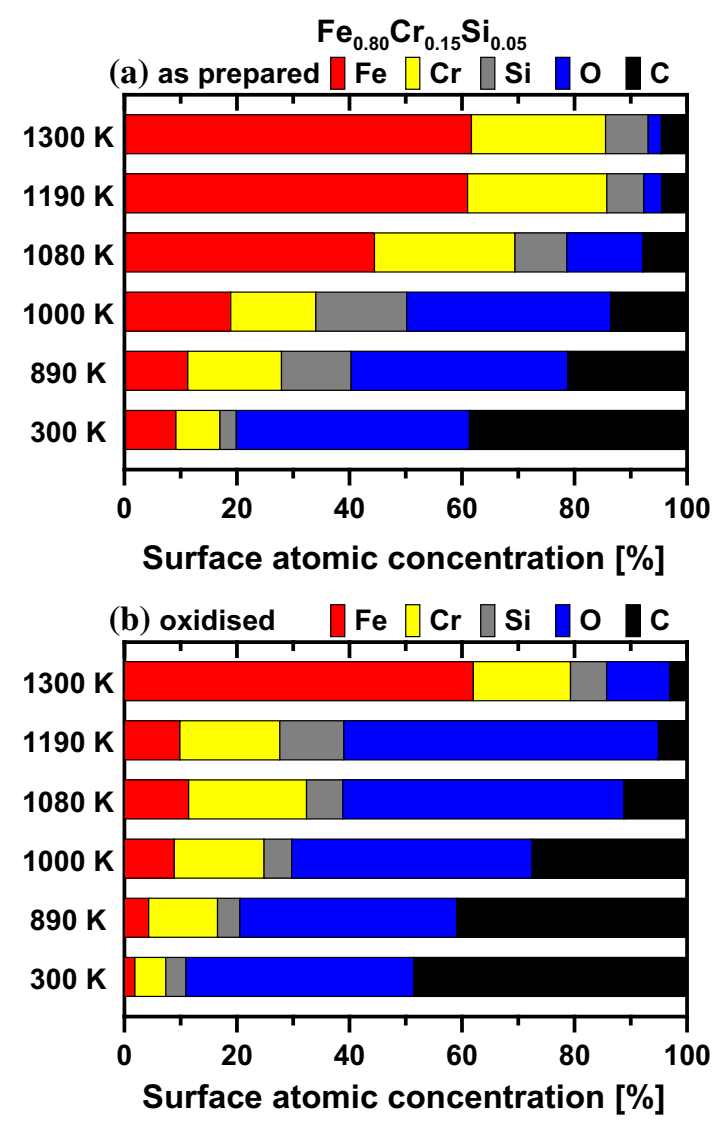

Fig. 7-(Color online) The surface atomic concentrations of selected elements for the as-prepared $(a)$ and oxidized $(b) \mathrm{Fe}_{0.80} \mathrm{Cr}_{0.15} \mathrm{Si}_{0.05}$ samples after annealing at various temperatures.

which is composed of three peaks (Figure 8(a)). The main one, marked for $\mathrm{Fe} 2 \mathrm{p}_{3 / 2}$, is $\mathrm{Fe}^{0}$ at the $\mathrm{BE}$ of 707.3 $\mathrm{eV}$, while the peaks at the $\mathrm{BE}$ of 708.9 and $710.8 \mathrm{eV}$ correspond to $\mathrm{Fe}^{2+}$ and $\mathrm{Fe}^{3+}$ species. The $\mathrm{Cr} 2 \mathrm{p}$ doublet (Figure 8(b)) exhibits two components at the positions of 574.7 and $576.5 \mathrm{eV}$ (for $2 \mathrm{p}_{3 / 2}$ ) which represent $\mathrm{Cr}^{0}$ and $\mathrm{Cr}^{3+}$ species. The analysis of the $\mathrm{Si}$ 2p spectrum (Figure 8(c)) allows to distinguish a dominant $\mathrm{Si}^{0}$ species $(\mathrm{BE}$ of $99.9 \mathrm{eV}$ ) and additional peak which probably represents a non-stoichiometric $\mathrm{Si}-\mathrm{O}_{x}$ bond (BE of $101.5 \mathrm{eV}){ }^{[15]}$ The $\mathrm{O}$ 1s spectrum (Figure $8(\mathrm{~d})$ ) is composed of two peaks at the BE of 530.8 and $531.9 \mathrm{eV}$, while $\mathrm{C}$ 1s signal (Figure 8(e)) exhibits three components at the position of 283.5, 284.8 , and $286.3 \mathrm{eV}$.

The XPS measurements performed for the oxidized $\mathrm{Fe}_{0.80} \mathrm{Cr}_{0.15} \mathrm{Si}_{0.05}$ alloy reveal that the iron, chromium, and silicon concentrations consequently increase during sample annealing up to $1080 \mathrm{~K}$. At this stage, the estimated surface atomic concentrations are $\mathrm{Fe}-11.4$ pct, $\mathrm{Cr}-21.0$ pct, $\mathrm{Si}-6.5$ pct, $\mathrm{O}-49.9$ pct, $\mathrm{C}-11.2$ pct (see Figure 7(b)-1080 K). Further annealing at $1190 \mathrm{~K}$ causes the decrease of $\mathrm{Fe}, \mathrm{Cr}$, and $\mathrm{C}$ contributions and increase of $\mathrm{Si}$ and $\mathrm{O}$ content. Finally, after annealing the sample at $1300 \mathrm{~K}$, the studied surface region is composed of 62 pct of $\mathrm{Fe}$ atoms, 12.3 pct of $\mathrm{Cr}$ atoms, $6.4 \mathrm{pct}$ of $\mathrm{Si}$ atoms, and only 11.3 pet of $\mathrm{O}$ atoms and 3.0 pct of $\mathrm{C}$ atoms (see Figure 7(b)-1300 K). High chromium concentration observed during all stages of thermal treatment indicates segregation of $\mathrm{Cr}$ to the surface region of the oxidized $\mathrm{Fe}_{0.80} \mathrm{Cr}_{0.15} \mathrm{Si}_{0.05}$ alloy. In addition, after annealing at $1300 \mathrm{~K}$, the oxygen content significantly decreases. In the case of the studied oxidized samples that effect is observed for the first time. It may suggest that the higher concentration of $\mathrm{Si}$ and $\mathrm{Cr}$ in this alloy indicates the formation of thinner passivation layer during the sample oxidation process. It will be discussed in a later section in more detail.

The results obtained for the final state of oxidized $\mathrm{Fe}_{0.80} \mathrm{Cr}_{0.15} \mathrm{Si}_{0.05}$ alloy (after annealing at $1300 \mathrm{~K}$ ) are presented at Figures 8(f) to (j). The Fe $2 p$ core-level line (Figure 8(f)) is quite similar to the $\mathrm{Fe}_{0.85} \mathrm{Cr}_{0.10} \mathrm{Si}_{0.05}$ alloy. The $2 \mathrm{p}_{3 / 2}$ peak exhibits three components, from which the dominant one represents $\mathrm{Fe}^{0}$ species at the $\mathrm{BE}$ of $707.3 \mathrm{eV}$, while the other two (at BE of 708.7 and $710.8 \mathrm{eV}$ ) correspond to $\mathrm{Fe}^{2+}$ and $\mathrm{Fe}^{3+}$ species. A line shape of $\mathrm{Cr} 2 \mathrm{p}$ spectrum is close to this observed for the as-prepared sample (see Figures $8(\mathrm{~g})$ and (b)). Three components are distinguished in the $\mathrm{Cr} 2 \mathrm{p}_{3 / 2}$ peak: 574.6, 576.2, and $577.8 \mathrm{eV}$, which correspond to $\mathrm{Cr}^{0}$ and $\mathrm{Cr}^{3+}$ species. In the case of the $\mathrm{Si} 2 \mathrm{p}$ spectrum, only $\mathrm{Si}^{0}$ peak is observed at the BE of $99.8 \mathrm{eV}$ (Figure 8(h)). The $\mathrm{O}$ 1s core-level line is composed of two peaks with maxima at the positions of 531.7 and $533.8 \mathrm{eV}$ (Figure 8(i)), while the maximum of $\mathrm{C} 1 \mathrm{~s}$ signal is around $284.7 \mathrm{eV}$ (the exact position cannot be identified due to the low signal/background intensity ratio, see Figure 8(j)).

\section{DISCUSSION}

As it was described above, all studied samples were prepared in the same way and then were subjected to the similar regime of thermal treatment in UHV. Firstly, it should be noted that the behavior of the adsorbed $\mathrm{C}$ atoms is similar for all studied as-obtained and oxidized $\mathrm{Fe}-\mathrm{Cr}-\mathrm{Si}$ alloys. The $\mathrm{C}$ contamination which is mainly connected with the direct contact of the studied samples with air during preparation procedure tends to systematically decrease with samples annealing in UHV. In addition, the detailed analysis of all XPS C 1s signals as well as results reported in Reference 27 showed that the adsorbed carbon atoms do not form any compounds with $\mathrm{Fe}, \mathrm{Cr}$, and $\mathrm{Si}$ in the studied $\mathrm{Fe}-\mathrm{Cr}-\mathrm{Si}$ alloys. Therefore, it seems that the influence of $\mathrm{C}$ atoms on the surface segregation process as well as corrosion of the studied alloys is negligibly small and due to that it will not be discussed further.

In general, it can be stated that the obtained results for all as-prepared samples are quite similar to each other. In the case of the oxidized samples, the applied thermal treatment allows to obtain different surface chemical compositions, which are probably directly related to the initial bulk concentration of both solutes. Taking this into account, the following discussion is divided into three separate parts. 


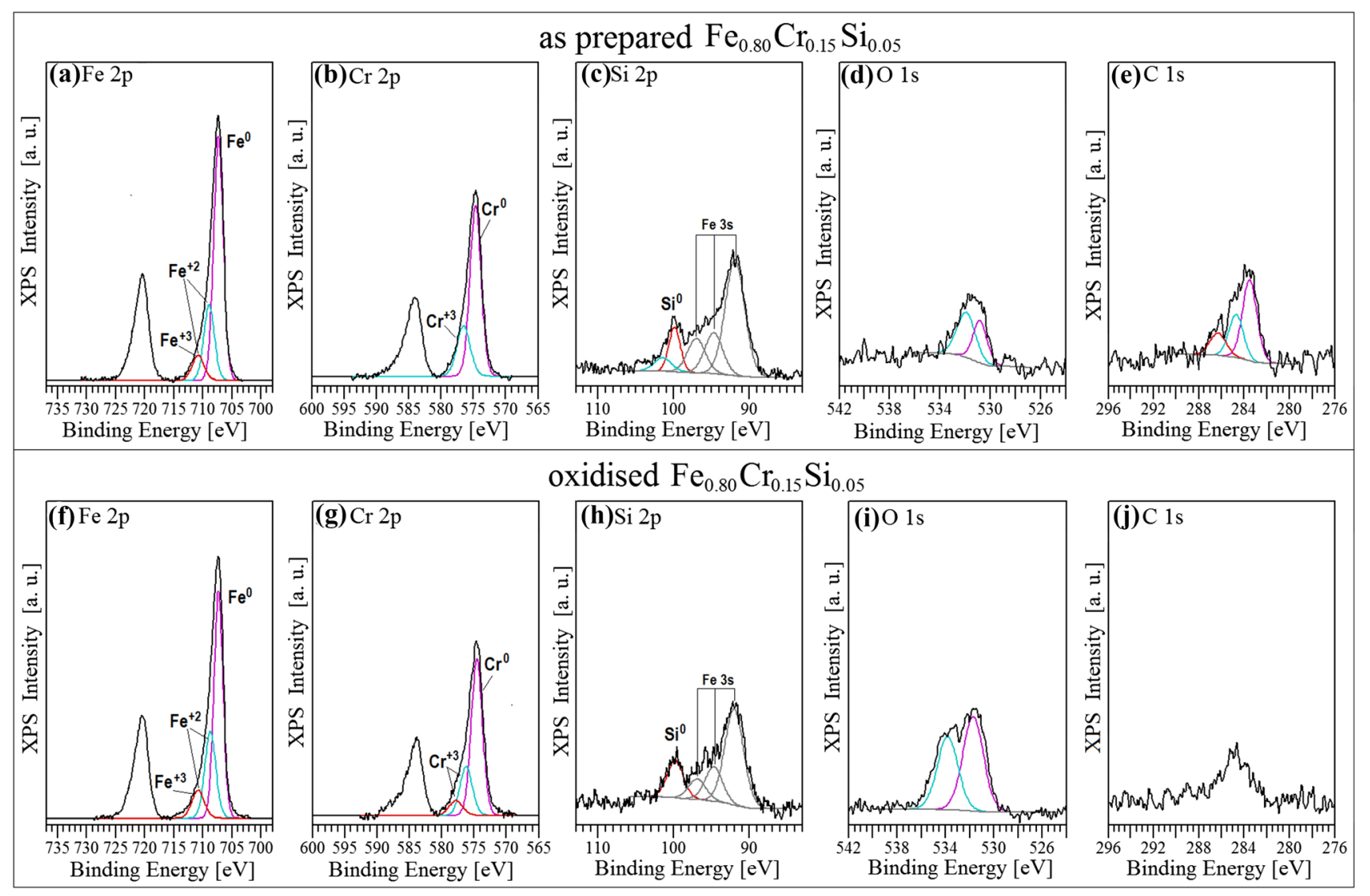

Fig. 8-(Color online) The selected XPS spectra (Fe 2p, Cr 2p, Si 2p, O 1s) for $\mathrm{Fe}_{0.80} \mathrm{Cr}_{0.15} \mathrm{Si}_{0.05}$ alloys: (a) to (e) the as-prepared sample after annealing in UHV at $1300 \mathrm{~K} ;(f)$ to $(j)$ the oxidized sample after annealing in UHV at $1300 \mathrm{~K}$.

Table I. Calculated $c_{\mathrm{Si}} / c_{\mathrm{Fe}}$ and $c_{\mathrm{Cr}} / c_{\mathrm{Fe}}$ Ratios for the As-Prepared Samples

\begin{tabular}{|c|c|c|c|c|c|c|c|c|}
\hline \multirow[b]{2}{*}{$T[\mathrm{~K}]$} & \multicolumn{2}{|c|}{$\mathrm{Fe}_{0.94} \mathrm{Cr}_{0.03} \mathrm{Si}_{0.03}$} & \multicolumn{2}{|c|}{$\mathrm{Fe}_{0.90} \mathrm{Cr}_{0.05} \mathrm{Si}_{0.05}$} & \multicolumn{2}{|c|}{$\mathrm{Fe}_{0.85} \mathrm{Cr}_{0.10} \mathrm{Si}_{0.05}$} & \multicolumn{2}{|c|}{$\mathrm{Fe}_{0.80} \mathrm{Cr}_{0.15} \mathrm{Si}_{0.05}$} \\
\hline & $c_{\mathrm{Si}} / c_{\mathrm{Fe}}$ & $c_{\mathrm{Cr}} / c_{\mathrm{Fe}}$ & $c_{\mathrm{Si}} / c_{\mathrm{Fe}}$ & $c_{\mathrm{Cr}} / c_{\mathrm{Fe}}$ & $c_{\mathrm{Si}} / c_{\mathrm{Fe}}$ & $c_{\mathrm{Cr}} / c_{\mathrm{Fe}}$ & $c_{\mathrm{Si}} / c_{\mathrm{Fe}}$ & $c_{\mathrm{Cr}} / c_{\mathrm{Fe}}$ \\
\hline RT & 0.51 & 0.00 & 0.38 & 0.15 & 0.36 & 0.47 & 0.32 & 0.85 \\
\hline 890 & 0.83 & 0.68 & 1.03 & 1.13 & 1.01 & 1.06 & 1.10 & 1.48 \\
\hline 1000 & 0.88 & 0.52 & 1.27 & 1.11 & 1.28 & 0.74 & 0.85 & 0.80 \\
\hline 1080 & 0.22 & 0.11 & 1.21 & 0.70 & 0.27 & 0.29 & 0.21 & 0.56 \\
\hline 1190 & 0.07 & 0.05 & 0.20 & 0.13 & 0.11 & 0.32 & 0.11 & 0.41 \\
\hline 1300 & 0.07 & 0.04 & 0.12 & 0.14 & 0.13 & 0.21 & 0.12 & 0.39 \\
\hline Bulk Ratio & 0.032 & 0.032 & 0.056 & 0.056 & 0.059 & 0.118 & 0.063 & 0.188 \\
\hline
\end{tabular}

\section{A. As-Prepared Samples}

Table I presents $c_{\mathrm{Si}} / c_{\mathrm{Fe}}$ and $c_{\mathrm{Cr}} / c_{\mathrm{Fe}}$ ratios for all as-prepared samples calculated according to Eq. 1. Despite the different bulk chemical composition of the studied alloys, the "diffusion behavior" of both solutes is quite similar for all samples. The much higher initial $c_{\mathrm{Si}} / c_{\mathrm{Fe}}$ and $c_{\mathrm{Cr}} / c_{\mathrm{Fe}}$ ratios than the corresponding $c_{\mathrm{Si}} / c_{\mathrm{Fe}}^{\text {bulk }}$ and $c_{\mathrm{Cr}} / c_{\mathrm{Fe}}^{\text {bulk }}$ ones indicate the strong surface segregation process of $\mathrm{Si}$ and $\mathrm{Cr}$ atoms during the samples preparation procedure. After the first annealing at $890 \mathrm{~K}$, the $c_{\mathrm{Si}} / c_{\mathrm{Fe}}$ and $c_{\mathrm{Cr}} / c_{\mathrm{Fe}}$ ratios increase significantly (in most cases, the obtained values are more than ten times higher than the corresponding bulk ratios). This means that despite the occurrence of solutes segregation during the sample preparation, the thermal treatment at UHV enhances this process. Annealing at $1000 \mathrm{~K}$ results in further increase of $c_{\mathrm{Si}} / c_{\mathrm{Fe}}$ values but $c_{\mathrm{Cr}} / c_{\mathrm{Fe}}$ ratios start to decrease. Above $1000 \mathrm{~K}$, a gradual decrease of both solute:iron ratios are observed. However, even after annealing at the highest temperature the surface $c_{\mathrm{Si}} / c_{\mathrm{Fe}}$ and $c_{\mathrm{Cr}} / c_{\mathrm{Fe}}$ ratios are still about two times higher than the bulk ones. The comparison of the values presented in Table I with the oxygen surface concentrations 
estimated for all as-prepared samples (Figures 1(a), 3(a), 5(a), 7(a)) indicates that the surface segregation process is strongly correlated with the presence of the oxygen atoms on the surface. As one can notice, up to $1000 \mathrm{~K}$ there are significant amounts of oxygen atoms at the alloy surfaces (41.9 pct for $\mathrm{Fe}_{0.94} \mathrm{Cr}_{0.03} \mathrm{Si}_{0.03}, 42.2$ pct for $\mathrm{Fe}_{0.90} \mathrm{Cr}_{0.05} \mathrm{Si}_{0.05}, 41.1$ pet for $\mathrm{Fe}_{0.85} \mathrm{Cr}_{0.10} \mathrm{Si}_{0.05}$, and 36.3 pct for $\mathrm{Fe}_{0.80} \mathrm{Cr}_{0.15} \mathrm{Si}_{0.05}$ ), while annealing at $1080 \mathrm{~K}$ induces rapid decrease of the oxygen contribution in the surface region.

According to the presented results, the evolution of the surface chemical composition of all as-prepared samples could be described as below. After melting and cold-rolling processes, the $\mathrm{Fe}-\mathrm{Cr}-\mathrm{Si}$ alloys foils were annealed in vacuum at $1270 \mathrm{~K}$. According to the work of Idczak et al.,"11] the "freezing" temperature for iron-based alloys which is defined as the upper limit of temperatures at which the diffusion of atoms in the material practically does not exist is about $700 \mathrm{~K}$. Taking this fact into account, it could be stated that during heating at temperatures above $700 \mathrm{~K}$ the $\mathrm{Si}$ and $\mathrm{Cr}$ atoms segregate to the surface region. After preparation, the samples were mounted in the UHV chamber and subsequently annealed. As it was shown above, after the first annealing in $\mathrm{UHV}$, the $c_{\mathrm{Si}} / c_{\mathrm{Fe}}$ and $c_{\mathrm{Cr}} / c_{\mathrm{Fe}}$ ratios increase rapidly. This effect could be explained by assuming the oxygen induced surface segregation of $\mathrm{Si}$ and $\mathrm{Cr}$ atoms. The initial presence of oxygen atoms at the alloy surface (as a contaminant) probably leads to additional surface segregation of $\mathrm{Si}$ and $\mathrm{Cr}$ atoms at temperatures above $700 \mathrm{~K}$. This phenomenon was observed many times in the case of iron-based alloys. ${ }^{[28,29]}$

On the basis of the results presented in Table I, it can be noticed that the maximum of $c_{\mathrm{Si}} / c_{\mathrm{Fe}}$ ratio for all measured as-prepared alloys are obtained after annealing at $1000 \mathrm{~K}$, while the maximum of $c_{\mathrm{Cr}} / c_{\mathrm{Fe}}$ ratio is after heating at $890 \mathrm{~K}$. It means that the sublimation of $\mathrm{Cr}$ oxides at elevated temperatures at a rate is faster than $\mathrm{Si}$ oxides. Further annealing at $1080 \mathrm{~K}$ and above induces mostly desorption of $\mathrm{O}$ atoms and also some amount of $\mathrm{Fe}, \mathrm{Cr}$, and $\mathrm{Si}$ oxides. Oxygen depletion in the surface region causes a significant slowdown of the segregation process and due to that the $c_{\mathrm{Si}} / c_{\mathrm{Fe}}$ and $c_{\mathrm{Cr}} /$ $c_{\mathrm{Fe}}$ ratios systematically decrease. In summary, this part of the study indicates that the surface segregation process of $\mathrm{Si}$ and $\mathrm{Cr}$ atoms occurs in all as-prepared $\mathrm{Fe}-\mathrm{Cr}-\mathrm{Si}$ alloys and, moreover, this process depends strongly on the presence of oxygen atoms at the alloy surface. The diffusion of $\mathrm{Cr}$ and $\mathrm{Si}$ atoms to the surface region is more effective when the surface contains of oxygen atoms.

\section{B. Oxidized $\mathrm{Fe}_{0.94} \mathrm{Cr}_{0.03} \mathrm{Si}_{0.03}$ and $\mathrm{Fe}_{0.90} \mathrm{Cr}_{0.05} \mathrm{Si}_{0.05}$ Samples}

Table II presents the $c_{\mathrm{Si}} / c_{\mathrm{Fe}}, c_{\mathrm{Cr}} / c_{\mathrm{Fe}}$ and $\mathrm{c}_{\mathrm{O}} /\left(\mathrm{c}_{\mathrm{Fe}}+\mathrm{c}_{\mathrm{Si}}\right.$ $+\mathrm{c}_{\mathrm{Cr}}$ ) ratios for the oxidized $\mathrm{Fe}_{0.94} \mathrm{Cr}_{0.03} \mathrm{Si}_{0.03}$ and $\mathrm{Fe}_{0.90} \mathrm{Cr}_{0.05} \mathrm{Si}_{0.05}$ samples. The comparison of the estimated $c_{\mathrm{Si}} / c_{\mathrm{Fe}}$ and $c_{\mathrm{Cr}} / c_{\mathrm{Fe}}$ ratios at $\mathrm{RT}$ with the corresponding ones obtained for the as-prepared samples reveals that the exposure to air at $870 \mathrm{~K}$ for 2 hours causes the additional segregation of $\mathrm{Si}$ atoms on the surface. Especially, in the case of $\mathrm{Fe}_{0.90} \mathrm{Cr}_{0.05} \mathrm{Si}_{0.05}$ alloy the initial $c_{\mathrm{Si}} / c_{\mathrm{Fe}}$ ratio is more than three times higher that $c_{\mathrm{Si}} / c_{\mathrm{Fe}}$ ratio for the as-prepared sample, while the $c_{\mathrm{Cr}} / c_{\mathrm{Fe}}$ ratio is close to zero. It can be stated that oxidation at high temperature, higher than the "freezing" temperature, induces diffusion of $\mathrm{Cr}$ atoms from the surface region toward deeper sample layers. This effect is rather surprising since the surface segregation of $\mathrm{Cr}$ atoms occurs in the as-obtained $\mathrm{Fe}-\mathrm{Cr}-\mathrm{Si}$ samples (Table I) as well in many binary $\mathrm{Fe}-\mathrm{Cr}$ alloys which were studied previously. $\left.{ }^{[4,}, 8-10,14\right]$ That result could be compared with the Mössbauer spectroscopy data obtained for similar systems. ${ }^{[16]}$ One of the conclusions which could be drawn from the high-temperature corrosion study of $\mathrm{Fe}-\mathrm{Cr}-\mathrm{Si}$ alloys is that the addition of a relatively small amount of $\mathrm{Cr}(\leq 5 \mathrm{pct})$ to the dilute iron-based $\mathrm{Fe}-\mathrm{Si}$ alloy does not improve the anti-corrosion properties of the alloy. All of that leads to the supposition that for the alloys with low bulk concentration of $\mathrm{Cr}$ and $\mathrm{Si}$ solutes, the role of $\mathrm{Cr}$ atoms in the high-temperature corrosion is negligibly small.

An evolution of the surface chemical composition of the oxidized $\mathrm{Fe}_{0.94} \mathrm{Cr}_{0.03} \mathrm{Si}_{0.03}$ and $\mathrm{Fe}_{0.90} \mathrm{Cr}_{0.05} \mathrm{Si}_{0.05}$ samples after annealing in UHV is quite obvious. The $c_{\mathrm{Cr}} /$ $c_{\mathrm{Fe}}$ ratios are still close to zero, while the $c_{\mathrm{Si}} / c_{\mathrm{Fe}}$ and $\mathrm{c}_{\mathrm{O}} /$ $\left(\mathrm{c}_{\mathrm{Fe}}+\mathrm{c}_{\mathrm{Si}}+\mathrm{c}_{\mathrm{Cr}}\right)$ decrease systematically with increasing temperature of annealing.

A XPS analysis of selected Fe $2 p_{3 / 2}$ and Si $2 p$ peaks for oxidized $\mathrm{Fe}_{0.90} \mathrm{Cr}_{0.05} \mathrm{Si}_{0.05}$ sample is presented in Figure 9 (the results for the $\mathrm{Fe}_{0.94} \mathrm{Cr}_{0.03} \mathrm{Si}_{0.03}$ alloy are similar and thus they are not shown here). At RT, the Fe $2 p$ core-level line is located in the binding energy range representing only iron oxides - deconvolution of $\mathrm{Fe} 2 \mathrm{p}_{3}$ 2 peak exhibits three components at $\mathrm{BE}$ of 710.4, 711.9, and $713.7 \mathrm{eV} .{ }^{[11,15]}$ At the same time, the Si $2 p$ spectrum is composed of two peaks at $\mathrm{BE}$ of 103.6 and $101.0 \mathrm{eV}$ which correspond to $\mathrm{SiO}_{2}$ and $\mathrm{SiO}_{x} \cdot{ }^{[15]}$ After annealing at $1000 \mathrm{~K}$, the chemical shifts are observed in the spectra. Iron components (corresponding to various oxides) are placed at 709.7, 711.5, and $713.5 \mathrm{eV}$, while the silicon peak is located at $103.0 \mathrm{eV}$ and is related to the presence of the $\mathrm{Fe}_{2} \mathrm{SiO}_{4}$ compound. ${ }^{[15,30]}$ According to the Mössbauer data taken for the oxidized $\mathrm{Fe}-\mathrm{Si}^{[15]}$ and $\mathrm{Fe}-\mathrm{Cr}-\mathrm{Si}{ }^{[16]}$ alloys, the formation of this oxide was not observed. It seems that the $\mathrm{Fe}_{2} \mathrm{SiO}_{4}$ is formed during sample oxidation in the deeper sample layers. After annealing at $1000 \mathrm{~K}$, the $c_{\mathrm{Si}} / c_{\mathrm{Fe}}$ and $c_{\mathrm{O}} /\left(c_{\mathrm{Fe}}+c_{\mathrm{Si}}+c_{\mathrm{Cr}}\right)$ ratios decrease by more than a half (Table II) which implies that significant amount of oxygen desorbs and the partially reduced iron and silicon oxides form additional $\mathrm{Fe}_{2} \mathrm{SiO}_{4}$ compound. ${ }^{[6,}{ }^{30]}$ Further annealing causes changes mostly in the Fe $2 p$ core-level line. The line shape changes on the higher binding energy site and two additional components could be observed with BE of 714.9 and $716.8 \mathrm{eV}$ which are the $\mathrm{Fe}^{2+}$ satellites. ${ }^{[1,23]}$ Finally, it is worth noting that all spectra presented in Figure 9 do not present the $\mathrm{Fe}^{0}$ and $\mathrm{Si}^{0}$ species. The comparison of this result with those obtained for the oxidized $\mathrm{Fe}_{0.95} \mathrm{Si}_{0.05}$ alloy, ${ }^{[15]}$ where annealing at similar temperatures revealed the presence of $\mathrm{Fe}^{0}$ and $\mathrm{Si}^{0}$ species, indicates that the oxygen atoms diffuse easier 
Table II. Calculated $c_{\mathrm{Si}} / c_{\mathrm{Fe}}, c_{\mathrm{Cr}} / c_{\mathrm{Fe}}$ and $c_{\mathrm{O}} /\left(c_{\mathrm{Fe}}+c_{\mathrm{Si}}+c_{\mathrm{Cr}}\right)$ Ratios for the Oxidized $\mathrm{Fe}_{0.94} \mathrm{Cr}_{0.03} \mathrm{Si}_{0.03}$ and $\mathrm{Fe}_{0.90} \mathrm{Cr}_{0.05} \mathrm{Si}_{0.05}$ Samples

\begin{tabular}{|c|c|c|c|c|c|c|}
\hline \multirow[b]{2}{*}{$T[\mathrm{~K}]$} & \multicolumn{3}{|c|}{$\mathrm{Fe}_{0.94} \mathrm{Cr}_{0.03} \mathrm{Si}_{0.03}$} & \multicolumn{3}{|c|}{$\mathrm{Fe}_{0.90} \mathrm{Cr}_{0.05} \mathrm{Si}_{0.05}$} \\
\hline & $c_{\mathrm{Si}} / c_{\mathrm{Fe}}$ & $c_{\mathrm{Cr}} / c_{\mathrm{Fe}}$ & $c_{\mathrm{O}} /\left(c_{\mathrm{Fe}}+c_{\mathrm{Si}}+c_{\mathrm{Cr}}\right)$ & $c_{\mathrm{Si}} / c_{\mathrm{Fe}}$ & $c_{\mathrm{Cr}} / c_{\mathrm{Fe}}$ & $c_{\mathrm{O}} /\left(c_{\mathrm{Fe}}+c_{\mathrm{Si}}+c_{\mathrm{Cr}}\right)$ \\
\hline RT & 0.52 & 0.00 & 2.30 & 1.43 & 0.00 & 5.06 \\
\hline 890 & 0.26 & 0.00 & 1.85 & 0.86 & 0.00 & 2.30 \\
\hline 1000 & 0.42 & 0.00 & 1.36 & 0.67 & 0.00 & 2.11 \\
\hline 1080 & 0.28 & 0.01 & 1.33 & 0.55 & 0.01 & 1.42 \\
\hline 1190 & 0.18 & 0.01 & 1.16 & 0.41 & 0.01 & 1.20 \\
\hline 1300 & 0.23 & 0.01 & 1.01 & 0.38 & 0.02 & 1.09 \\
\hline Bulk Ratio & 0.032 & 0.032 & - & 0.056 & 0.056 & - \\
\hline
\end{tabular}

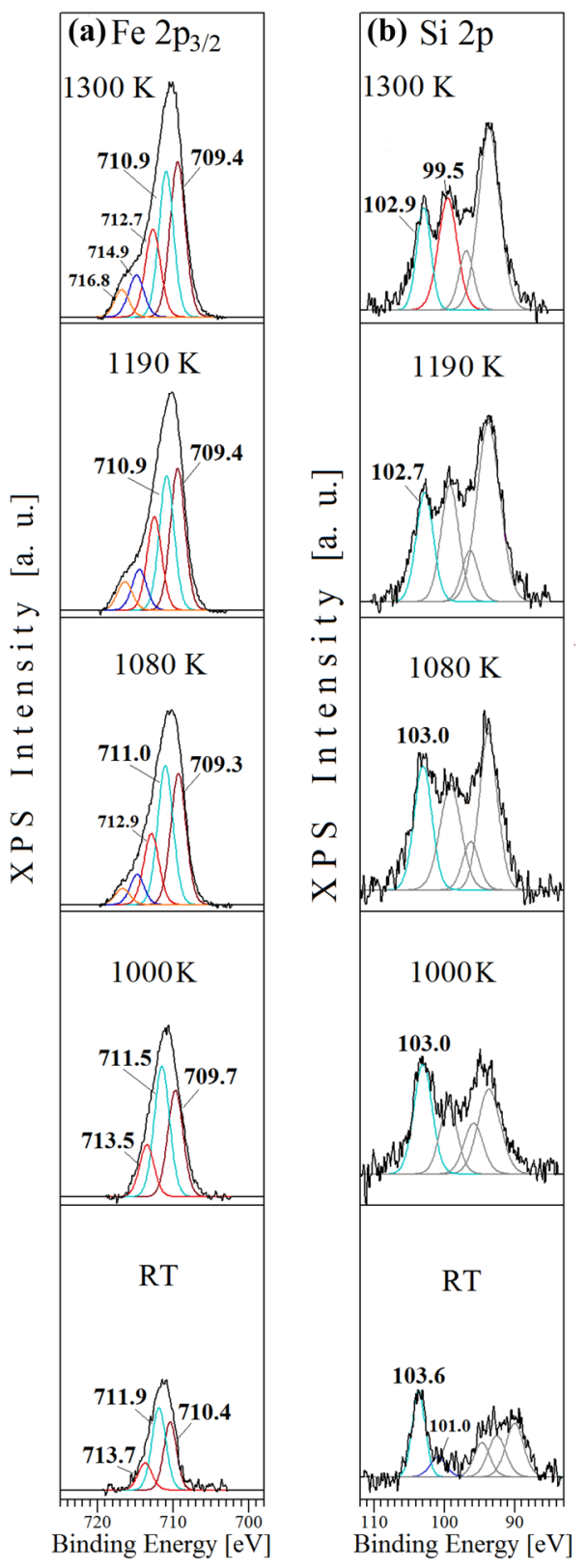

Fig. 9-(Color online) The selected XPS spectra for the $\mathrm{Fe}_{0.90} \mathrm{Cr}_{0.05} \mathrm{Si}_{0.05}$ alloy after annealing at various temperatures: $(a) \mathrm{Fe}$ $2 \mathrm{p}_{3 / 2}$ peak, (b) Si $2 \mathrm{p}$ spectrum. into deeper parts of the $\mathrm{Fe}_{0.90} \mathrm{Cr}_{0.05} \mathrm{Si}_{0.05}$ alloy than it was observed for the $\mathrm{Fe}_{0.95} \mathrm{Si}_{0.05}$ one. This result confirms the observation that the addition of a relatively small amount of $\mathrm{Cr}(\leq 5 \mathrm{pct})$ to the dilute iron-based Fe-Si alloy does not improve the anti-corrosion properties of the alloy. According to this part of discussion that effect is mainly connected with the absence of $\mathrm{Cr}$ atoms in the surface region.

\section{Oxidized $\mathrm{Fe}_{0.85} \mathrm{Cr}_{0.10} \mathrm{Si}_{0.05}$ and $\mathrm{Fe}_{0.80} \mathrm{Cr}_{0.15} \mathrm{Si}_{0.05}$ Samples}

The values of $c_{\mathrm{Si}} / c_{\mathrm{Fe}}, c_{\mathrm{Cr}} / c_{\mathrm{Fe}}$ and $c_{\mathrm{O}} /\left(c_{\mathrm{Fe}}+c_{\mathrm{Si}}+c_{\mathrm{Cr}}\right)$ ratios presented in Table III and the detailed deconvolution of selected peaks arranged in Figure 10 (for $\mathrm{Fe}_{0.80} \mathrm{Cr}_{0.15} \mathrm{Si}_{0.05}$ alloy as an example) reveal a systematic desorption of oxides caused by the thermal treatment of the oxidized $\mathrm{Fe}_{0.85} \mathrm{Cr}_{0.10} \mathrm{Si}_{0.05}$ and $\mathrm{Fe}_{0.80} \mathrm{Cr}_{0.15} \mathrm{Si}_{0.05}$ samples. As one can notice, the initial $c_{\mathrm{Si}} / c_{\mathrm{Fe}}$ and $c_{\mathrm{Cr}} / c_{\mathrm{Fe}}$ ratios are much higher than the corresponding ones for the as-prepared samples (Table I), which means that during the oxidation process both solutes additionally segregate to the surface. At the same time, comparing the initial $c_{\mathrm{Si}} / c_{\mathrm{Fe}}$ and $c_{\mathrm{Cr}} / c_{\mathrm{Fe}}$ ratios estimated for the oxidized $\mathrm{Fe}_{0.90} \mathrm{Cr}_{0.05} \mathrm{Si}_{0.05}$ (Table II) and $\mathrm{Fe}_{0.85} \mathrm{Cr}_{0.10} \mathrm{Si}_{0.05}$ (Table III) samples it can be clearly seen that increasing the bulk chromium content from 5 at. pet to 10 pct induces opposite diffusion direction of $\mathrm{Cr}$ atoms during the high-temperature oxidation process. Moreover, taking into account Mössbauer data which show that the high-temperature corrosion of $\mathrm{Fe}_{0.85} \mathrm{Cr}_{0.10} \mathrm{Si}_{0.05}$ alloy is almost stopped at $870 \mathrm{~K}$ and $1070 \mathrm{~K}$, while in the case of $\mathrm{Fe}_{0.96} \mathrm{Cr}_{0.03} \mathrm{Si}_{0.01}, \mathrm{Fe}_{0.94} \mathrm{Cr}_{0.03} \mathrm{Si}_{0.03}$, and $\mathrm{Fe}_{0.90} \mathrm{Cr}_{0.05} \mathrm{Si}_{0.05}$ samples a rather fast corrosion rates were observed, ${ }^{[16]}$ it seems that the surface passivation layer which could prevent further diffusion of oxygen into deeper regions of the $\mathrm{Fe}-\mathrm{Cr}-\mathrm{Si}$ alloy must be composed of both $\mathrm{Si}$ and $\mathrm{Cr}$ oxides.

Annealing the samples at $890 \mathrm{~K}$ and $1000 \mathrm{~K}$ causes the decrease of $c_{\mathrm{Si}} / c_{\mathrm{Fe}}, c_{\mathrm{Cr}} / c_{\mathrm{Fe}}$ and $c_{\mathrm{O}} /\left(c_{\mathrm{Fe}}+c_{\mathrm{Si}}+c_{\mathrm{Cr}}\right)$ ratios indicating the successive desorption of oxygen as well as various oxides from the surface. At this stage of experiment, the $\mathrm{Cr}$ and $\mathrm{Si}$ diffusion toward the alloy/ oxide interface occurs. Core-level lines, describing iron, chromium, and silicon compounds, change in shapes 
after annealing at $890 \mathrm{~K}$ and $1000 \mathrm{~K}$ and exhibit numerous of components (Figure 10). In the $\mathrm{Fe} 2 \mathrm{p}_{3 / 2}$ peak, four components are distinguished from which the metallic Fe occurs at BE of $707.3 \mathrm{eV}$ and the rest, placed at $708.8,710.1$, and $711.8 \mathrm{eV}$, correspond to $\mathrm{Fe}^{2+}$ and $\mathrm{Fe}^{3+}$ species. The $\mathrm{Cr} 2 \mathrm{p}_{3 / 2}$ peak is divided into three components at the $\mathrm{BE}$ of 576.2, $577.6\left(\mathrm{Cr}^{3+}\right)$ and 579.2 $\mathrm{eV}\left(\mathrm{Cr}^{6+}\right) .{ }^{[14]}$ The $\mathrm{Si} 2 \mathrm{p}$ spectrum exhibits two components, from which more dominant is $\mathrm{SiO}_{2}$ at position of $103.2 \mathrm{eV}$ (shifted by $0.3 \mathrm{eV}$ in comparison to maximum at $\mathrm{RT}$ ) and $\mathrm{Si}^{0}$ at position of $99.7 \mathrm{eV} .{ }^{[15]}$ In contrast to results obtained for the oxidized $\mathrm{Fe}_{0.90} \mathrm{Cr}_{0.05} \mathrm{Si}_{0.05}$ sample, the presence of $\mathrm{Fe}_{2} \mathrm{SiO}_{4}$ is not detected.

Annealing the samples at $1080 \mathrm{~K}$ and $1190 \mathrm{~K}$ induces increase of the $c_{\mathrm{Si}} / c_{\mathrm{Fe}}$ and $c_{\mathrm{Cr}} / c_{\mathrm{Fe}}$ ratios, while $c_{\mathrm{O}} /$ $\left(c_{\mathrm{Fe}}+c_{\mathrm{Si}}+c_{\mathrm{Cr}}\right)$ is still decreasing. It means that during these stages of thermal treatment, the further desorption of oxygen and oxides occurs. The Fe $2 \mathrm{p}_{3 / 2}$ spectrum is still composed of several peaks, but their relative contribution is different. The dominant one is $\mathrm{Fe}^{0}$ with the contribution in iron signal higher than 50 pct. In the $\mathrm{Cr} 2 \mathrm{p}_{3 / 2}$ and $\mathrm{Si} 2 \mathrm{p}$ spectra, the peaks corresponding to metallic $\mathrm{Cr}(574.6 \mathrm{eV})$ and $\mathrm{Si}^{0}(99.7$ $\mathrm{eV})$ are also observed. Comparing this with results obtained for oxidized $\mathrm{Fe}_{0.88} \mathrm{Cr}_{0.12}$ and $\mathrm{Fe}_{0.85} \mathrm{Cr}_{0.15}$ alloys in Reference 14, where after samples annealing, the metallic Fe detected was detected but a dominant species were $\mathrm{Fe}^{2+}$ and $\mathrm{Fe}^{3+},{ }^{[14]}$ it can be pointed out that by adding to $\mathrm{Fe}-\mathrm{Cr}$ alloys, with a higher bulk chromium content, an additional Si solute, the corrosion resistivity can be improved. Moreover, detection in the XPS spectra signals from metallic $\mathrm{Fe}, \mathrm{Cr}$, and $\mathrm{Si}$ indicates that the thickness of the oxide layer becomes smaller than the XPS sampling depth.

After the last annealing at $1300 \mathrm{~K}$, a significant decrease of the $c_{\mathrm{Si}} / c_{\mathrm{Fe}}, c_{\mathrm{Cr}} / c_{\mathrm{Fe}}$ and $c_{\mathrm{O}} /\left(c_{\mathrm{Fe}}+c_{\mathrm{Si}}+c_{\mathrm{Cr}}\right)$ ratios is observed. For the oxidized $\mathrm{Fe}_{0.80} \mathrm{Cr}_{0.15} \mathrm{Si}_{0.05}$ alloy, $c_{\mathrm{O}} /\left(c_{\mathrm{Fe}}+c_{\mathrm{Si}}+c_{\mathrm{Cr}}\right)$ ratio is the lowest of all oxidized samples, which means that the measured surface region is mostly composed of pure alloy elements. In addition, the detailed deconvolution of the $\mathrm{Fe}$ $2 \mathrm{p}_{3 / 2}, \mathrm{Cr} 2 \mathrm{p}_{3 / 2}$ and $\mathrm{Si} 2 \mathrm{p}$ spectra reveals that the $\mathrm{Fe}^{0}$, $\mathrm{Cr}^{0}$, and $\mathrm{Si}^{0}$ components are dominant (Figure 10). The $\mathrm{Fe} 2 \mathrm{p}_{3 / 2}$ peak is composed of three peaks representing: metallic $\mathrm{Fe}^{0}$ at $\mathrm{BE}$ of $707.3 \mathrm{eV}, \mathrm{Fe}^{2+}$, and $\mathrm{Fe}^{3+}$ species at $\mathrm{BE}$ of 708.7 and $710.8 \mathrm{eV}$. In the $\mathrm{Cr} 2 \mathrm{p}_{3 / 2}$ core-level line, the main component becomes metallic $\mathrm{Cr}$ at the position of $574.6 \mathrm{eV}$, while the other two correspond to $\mathrm{Cr}^{3+}$. In the $\mathrm{Si}$ spectrum, only $\mathrm{Si}^{0}$ peak is distinguished at the $\mathrm{BE}$ of $99.8 \mathrm{eV}$. These results confirm the Mossbauer data which show that the exposure of the $\mathrm{Fe}_{0.85} \mathrm{Cr}_{0.10} \mathrm{Si}_{0.05}$ alloy to air at $870 \mathrm{~K}$ for 2 hours causes the formation of only very thin oxide layer (less than 20 $\mathrm{nm}$ ) and it could be easily removed from the alloy surface by the applied thermal treatment. ${ }^{[16]}$

According to the presented data, it can be stated that the anti-corrosion properties of the $\mathrm{Fe}-\mathrm{Cr}-\mathrm{Si}$ alloys strongly depend on several factors. The most important one is the segregation of both solutes to the surface during the oxidation process, which strongly depends on their initial bulk concentration. In other words, the passive film, which prevents further diffusion of oxygen atoms into deeper sample layer, must be composed of $\mathrm{Cr}$ and $\mathrm{Si}$ oxides. As in the case of binary $\mathrm{Fe}-\mathrm{Cr}{ }^{[14]}$ and $\mathrm{Fe}-\mathrm{Si}^{[15]}$ alloys, where this condition cannot be fulfilled, the absence of $\mathrm{Cr}$ atoms in the surface region of the oxidized $\mathrm{Fe}_{0.94} \mathrm{Cr}_{0.03} \mathrm{Si}_{0.03}$ and $\mathrm{Fe}_{0.90} \mathrm{Cr}_{0.05} \mathrm{Si}_{0.05}$ alloys is mainly responsible for the relatively fast oxidation rate. At the same time, the corrosion properties of the $\mathrm{Fe}_{0.85} \mathrm{Cr}_{0.10} \mathrm{Si}_{0.05}$ and $\mathrm{Fe}_{0.80} \mathrm{Cr}_{0.15} \mathrm{Si}_{0.05}$ alloys are greatly enhanced since during the oxidation procedure both solutes strongly segregate to the surface.

Another important issue is the presence of the fayalite compound. The XPS data obtained for the oxidized $\mathrm{Fe}_{0.96} \mathrm{Si}_{0.04}, \mathrm{Fe}_{0.95} \mathrm{Si}_{0.05}$, and $\mathrm{Fe}_{0.90} \mathrm{Si}_{0.10}$ alloys in Reference 15 as well as the results presented in this work reveal the presence of $\mathrm{Fe}_{2} \mathrm{SiO}_{4}$ in the surface regions of $\mathrm{Fe}_{0.94} \mathrm{Cr}_{0.03} \mathrm{Si}_{0.03}$ and $\mathrm{Fe}_{0.90} \mathrm{Cr}_{0.05} \mathrm{Si}_{0.05}$ samples; however, in the case of $\mathrm{Fe}_{0.85} \mathrm{Cr}_{0.10} \mathrm{Si}_{0.05}$ and $\mathrm{Fe}_{0.80} \mathrm{Cr}_{0.15} \mathrm{Si}_{0.05}$ alloys, all measured $\mathrm{Si} 2 \mathrm{p}$ spectra present only the $\mathrm{SiO}_{2}$ components (together with the $\mathrm{Si}^{0}$ after annealing). At this time, it should be pointed out that the presence or absence of the $\mathrm{Fe}_{2} \mathrm{SiO}_{4}$ compound is not directly connected with the initial $\mathrm{Si}$ bulk concentration but with the presence of $\mathrm{Cr}$ atoms in the passivation layer (occurrence of chromium segregation to the surface region). Similar observation has been made by Moon et al. in Reference 31 who studied the initial oxidation resistance of $\mathrm{Fe}-\mathrm{Cr}$-Si alloys in $1200{ }^{\circ} \mathrm{C}$ steam, as a function of $\mathrm{Cr}$ concentration. They reported that $\mathrm{FeCr}_{2} \mathrm{O}_{4}, \mathrm{Fe}_{2} \mathrm{SiO}_{4}$, and islands of amorphous $\mathrm{SiO}_{2}$ are present in the oxide layer of $\mathrm{Fe}_{86} \mathrm{Cr}_{12} \mathrm{Si}_{2}$ and $\mathrm{Fe}_{84} \mathrm{Cr}_{16} \mathrm{Si}_{2}$, while $\mathrm{Cr}_{2} \mathrm{O}_{3}$ and continuous amorphous $\mathrm{SiO}_{2}$ films are observed in the oxide layer of the $\mathrm{Fe}_{78} \mathrm{Cr}_{20} \mathrm{Si}_{2}$ alloy. They concluded that due to sufficient Cr content, the $\mathrm{Fe}_{78} \mathrm{Cr}_{20} \mathrm{Si}_{2}$ alloy forms a $\mathrm{Cr}_{2} \mathrm{O}_{3}$ oxide layer and under the protection of the $\mathrm{Cr}_{2} \mathrm{O}_{3}$ oxide layer, $\mathrm{Si}$ can react with oxygen and form a continuous, amorphous $\mathrm{SiO}_{2}$ layer. The fast formation of $\mathrm{Cr}_{2} \mathrm{O}_{3}$ plays a key role in the formation of the continuous $\mathrm{SiO}_{2}$ layer and the resultant oxidation resistance of the $\mathrm{Fe}-\mathrm{Cr}-\mathrm{Si}$ alloys with higher $\mathrm{Cr}$ content.

Finally, what should be also taken into account is the oxygen induced surface segregation of solutes (both $\mathrm{Cr}$ and $\mathrm{Si}$ atoms) during annealing in UHV. As it is shown for the as-prepared samples, the initial oxidation (preoxidation) of the alloys, which was connected with their direct contact with air, causes additional strong segregation of both solvents during annealing them at temperatures below $1000 \mathrm{~K}$.

\section{CONCLUSIONS}

The XPS study of the as-prepared and oxidized $\mathrm{Fe}-\mathrm{Cr}-\mathrm{Si}$ alloys greatly expands the knowledge about the surface segregation process of the $\mathrm{Cr}$ and $\mathrm{Si}$ atoms during the sample preparation and provides information about changes in chemical composition of surface regions caused by annealing the samples at various temperatures in UHV. The obtained results together with TMS and CEMS data reported previously give a clear evidence that the anti-corrosion properties of these alloys strongly depend on the initial bulk concentration 
Table III. Calculated $c_{\mathrm{Si}} / c_{\mathrm{Fe}}, c_{\mathrm{Cr}} / c_{\mathrm{Fe}}$ and $c_{\mathrm{O}} /\left(c_{\mathrm{Fe}}+c_{\mathrm{Si}}+c_{\mathrm{Cr}}\right)$ Ratios for the Oxidized $\mathrm{Fe}_{0.85} \mathrm{Cr}_{0.10} \mathrm{Si}_{0.05}$ and $\mathrm{Fe}_{0.80} \mathrm{Cr}_{0.15} \mathrm{Si}_{0.05}$ Samples

\begin{tabular}{|c|c|c|c|c|c|c|}
\hline \multirow[b]{2}{*}{$T[\mathrm{~K}]$} & \multicolumn{3}{|c|}{$\mathrm{Fe}_{0.85} \mathrm{Cr}_{0.10} \mathrm{Si}_{0.05}$} & \multicolumn{3}{|c|}{$\mathrm{Fe}_{0.80} \mathrm{Cr}_{0.15} \mathrm{Si}_{0.05}$} \\
\hline & $c_{\mathrm{Si}} / c_{\mathrm{Fe}}$ & $c_{\mathrm{Cr}} / c_{\mathrm{Fe}}$ & $c_{\mathrm{O}} /\left(c_{\mathrm{Fe}}+c_{\mathrm{Si}}+c_{\mathrm{Cr}}\right)$ & $c_{\mathrm{Si}} / c_{\mathrm{Fe}}$ & $c_{\mathrm{Cr}} / c_{\mathrm{Fe}}$ & $c_{\mathrm{O}} /\left(c_{\mathrm{Fe}}+c_{\mathrm{Si}}+c_{\mathrm{Cr}}\right)$ \\
\hline RT & 1.26 & 0.86 & 4.30 & 1.92 & 2.95 & 3.71 \\
\hline 890 & 0.81 & 0.82 & 1.88 & 0.92 & 2.83 & 1.88 \\
\hline 1000 & 0.30 & 0.56 & 1.65 & 0.55 & 1.80 & 1.44 \\
\hline 1080 & 0.49 & 1.22 & 1.41 & 0.57 & 1.84 & 1.29 \\
\hline 1190 & 1.08 & 2.21 & 1.57 & 1.16 & 1.80 & 1.43 \\
\hline 1300 & 0.33 & 0.38 & 0.57 & 0.10 & 0.28 & 0.13 \\
\hline Bulk Ratio & 0.059 & 0.118 & - & 0.063 & 0.188 & - \\
\hline
\end{tabular}

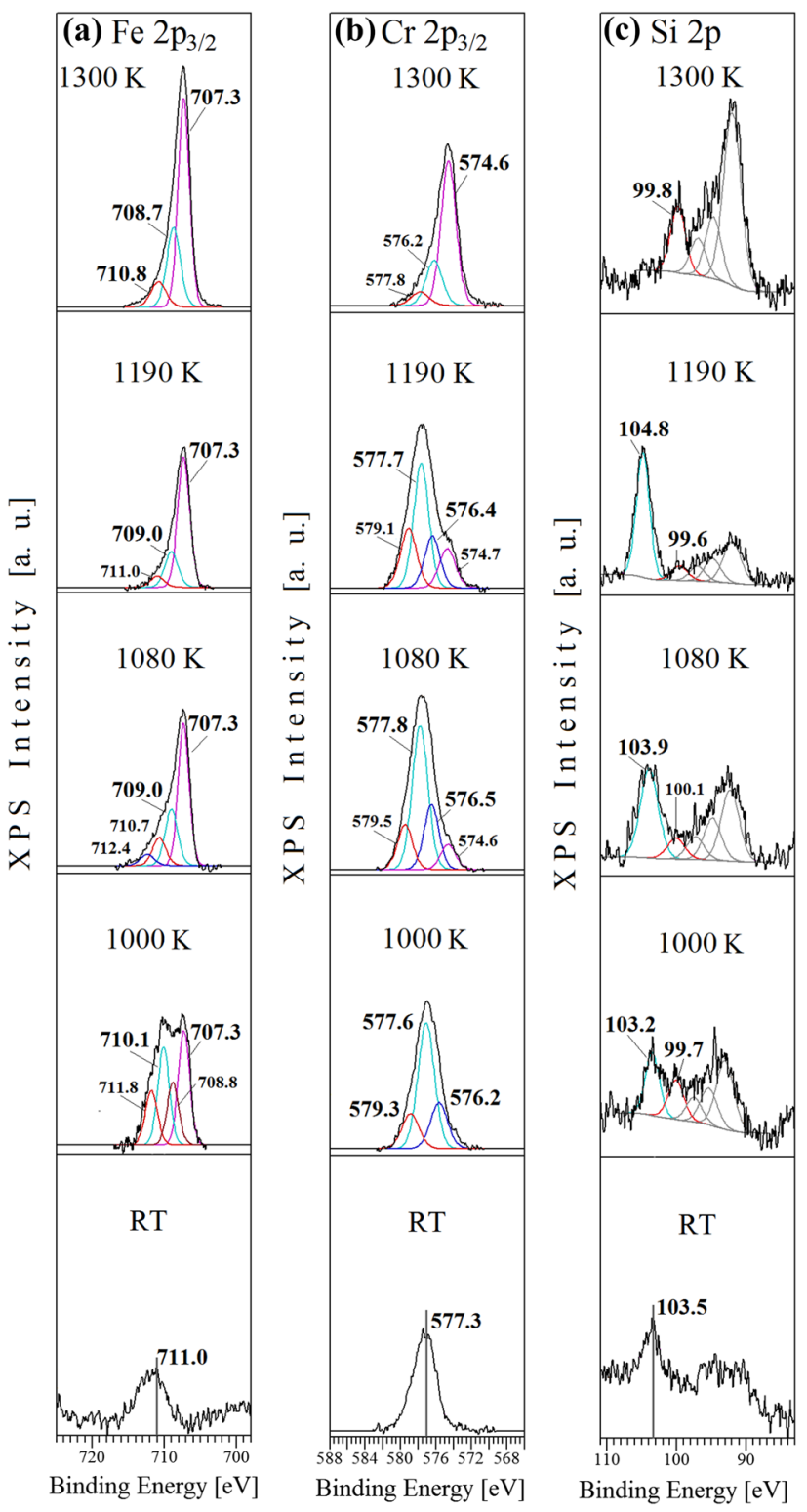

Fig. 10-(Color online) The selected XPS spectra for the $\mathrm{Fe}_{0.90} \mathrm{Cr}_{0.15} \mathrm{Si}_{0.05}$ alloy after annealing at various temperatures: $(a) \mathrm{Fe}$ $2 \mathrm{p}_{3 / 2}$ peak, (b) Cr $2 \mathrm{p}_{3 / 2}$ peak, (c) Si $2 \mathrm{p}$ peak. of both $\mathrm{Cr}$ and $\mathrm{Si}$ solutes. During the oxidation of samples with various initial $\mathrm{Cr}$ and Si bulk contents, the different passive films were formed. In the case of alloys with low chromium concentration $\left(\mathrm{Fe}_{0.94} \mathrm{Cr}_{0.03} \mathrm{Si}_{0.03}\right.$ and $\mathrm{Fe}_{0.90} \mathrm{Cr}_{0.05} \mathrm{Si}_{0.05}$ ), only silicon segregation occurred and in the surface region only iron oxides, silicon oxides, and fayalite were observed. However, for the alloys with higher chromium concentration $\left(\mathrm{Fe}_{0.85} \mathrm{Cr}_{0.10} \mathrm{Si}_{0.05}\right.$ and $\mathrm{Fe}_{0.80} \mathrm{Cr}_{0.15} \mathrm{Si}_{0.05}$ ), both solutes strongly segregate to the surface region, forming a protective passive layer, through which a significantly smaller amount of oxygen can penetrate the alloy (comparing with the oxidized film in other samples). The analysis of XPS spectra allows to distinguish iron, chromium, and silicon oxides, while no fayalite is detected. Annealing samples at high temperatures allows to obtain signal from the pure alloy elements. This fact could be also connected with good anti-corrosion properties of these alloys. Moreover, according to the obtained results the observed surface segregation process of $\mathrm{Cr}$ and $\mathrm{Si}$ atoms can be greatly enhanced by the presence of adsorbed oxygen atoms at the alloy surface. Therefore, the proper alloy preparation procedure with two additional stages, the initial low-temperature oxidation (for example, direct contact with air at RT) and subsequent annealing in vacuum at temperature lower than $1000 \mathrm{~K}$, could lead to significant increase of corrosion resistance of the $\mathrm{Fe}-\mathrm{Cr}-\mathrm{Si}$ alloys with smaller bulk concentration of both solutes. This is extremely important since the high concentration of $\mathrm{Cr}$ and/or $\mathrm{Si}$ atoms in iron matrix often leads to the formation of brittle intermetallic phases and precipitates which reduces the mechanical properties of the prepared alloys. Finally, it should be noted that this type of material is relatively cheap and easy to produce and it can be widely used in the modern industry.

\section{ACKNOWLEDGMENT}

This work was supported by the Polish Ministry of Science and Higher Education under the "Iuventus Plus" programme in the years $2015-17$, project number IP2014 015573. 


\section{OPEN ACCESS}

This article is licensed under a Creative Commons Attribution 4.0 International License, which permits use, sharing, adaptation, distribution and reproduction in any medium or format, as long as you give appropriate credit to the original author(s) and the source, provide a link to the Creative Commons licence, and indicate if changes were made. The images or other third party material in this article are included in the article's Creative Commons licence, unless indicated otherwise in a credit line to the material. If material is not included in the article's Creative Commons licence and your intended use is not permitted by statutory regulation or exceeds the permitted use, you will need to obtain permission directly from the copyright holder. To view a copy of this licence, visit http://creat ivecommons.org/licenses/by/4.0/.

\section{REFERENCES}

1. S. Khanna: Introduction to High Temperature Oxidation and Corrosion, Metals Park, OH, USA, ASM Int., 2002.

2. N. Birks, G.H. Meier, and F.S. Pettit: Introduction to High Temperature Oxidation of Metals, 2nd ed., Cambridge University, New York, NY, USA, 2006.

3. D. J. Young, High Temperature Oxidation and Corrosion of Metals, 2nd ed.; Elsevier Science, Amsterdam, 2016. ISBN: 978-0-08-100101-1.

4. S. Suzuki, T. Kosaka, H. Inoue, M. Isshiki, and Y. Waseda: Appl. Surf. Sci., 1996, vol. 103, pp. 495-502, https://doi.org/10.1016/ S0169-4332(96)00552-1.

5. V. Blum, A. Schmidt, W. Meier, L. Hammer, and K. Heinz: $J$. Phys.: Condens. Matter, 2003, vol. 15, pp. 3517-29, https:// doi.org/10.1088/0953-8984/15/21/302.

6. I. Parezanowic and M. Spiegel: Surf. Engineer., 2004, vol. 20, pp. 285-91, https://doi.org/10.1179/026708404225016517.

7. M. Vondracek, V. Dudr, N. Tsud, P. Lejcek, V. Chab, K.C. Prince, V. Matolin, and O. Schneeweiss: Surf. Sci., 2006, vol. 600 , pp. $4108-12$, https://doi.org/10.1016/j.susc.2006.01.129.

8. A. Kiejna and E. Wachowicz: Phys. Rev. B, 2008, vol. 78, p. 113403, https://doi.org/10.1103/PhysRevB.78.113403.

9. S. Schonecker, S.K. Kwon, B. Johansson, and L. Vitos: J. Phys. Condens. Matter, 2013, vol. 13, p. 305002, https://doi.org/10.1088/ 0953-8984/25/30/305002.

10. R. Idczak, K. Idczak, and R. Konieczny: J. Nucl. Mater., 2014, vol. $452, \quad$ pp. 141-46, https://doi.org/10.1016/ j.jnucmat.2014.05.003.
11. K. Idczak, R. Idczak, and R. Konieczny: Physica B, 2016, vol. 491, pp. 37-45, https://doi.org/10.1016/j.physb.2016.03.018.

12. R. Idczak, Oxid. Met., 2017, vol. 87, pp. 75-88. 10.1007/ s11085-016-9658-4.

13. R. Idczak: Appl. Phys. A, 2016, vol. 122, p. 1009, https://doi.org/ 10.1007/s00339-016-0544-3.

14. R. Idczak, K. Idczak, and R. Konieczny: Physica B, 2018, vol. 528, pp. 27-36, https://doi.org/10.1016/j.physb.2017.10.082.

15. R. Idczak, K. Idczak, and R. Konieczny: Corrosion, 2018, vol. 74, pp. 623-34, https://doi.org/10.5006/2676.

16. R. Idczak: Corrosion, 2018, vol. 74, pp. 1083-92, https://doi.org/ $10.5006 / 2776$.

17. V. Crist: Handbooks of Monochromatic XPS Spectra, XPS Interantional Inc., California, USA, The Elements and Native Oxides, 1999, vol. 1.

18. R. Idczak, R. Konieczny, and J. Chojcan: J. Appl. Phys., 2014, vol. 115, p. 103513, https://doi.org/10.1063/1.4868471

19. S. Cui and I.H. Jung: Metall. Mater. Trans. A, 2017, vol. 48A, pp. 4342-55, https://doi.org/10.1007/s11661-017-4163-1.

20. R.P. Gupta and S.K. Sen: Phys. Rev. B., 1975, vol. 12, pp. 12-15, https://doi.org/10.1103/PhysRevB.12.15.

21. J.H. Scofield: J. Electron Spectrosc., 1976, vol. 8, pp. 129-37, https://doi.org/10.1016/0368-2048(76)80015-1.

22. S. Tanuma, C.J. Powell, and D.R. Penn: Surf. Interface Anal., 1994, vol. 21, pp. 165-76, https://doi.org/10.1002/sia.740210302.

23. A.P. Grosvenor, B.A. Kobe, M.C. Biesinger, and N.S. McIntyre: Surf. Interace Anal., 2004, vol. 36, pp. 1564-74, https://doi.org/ 10.1002/sia.1984.

24. A. Idhil, C. N. Borca, A.-C. Uldry, N. Zema, S. Turchini, D. Catone, A. Foelske, D. Grolimund, M. Samaras, Nucl. Instrum. Methods In Physics Research B, 2012, vol. 284, pp. 1-5, https://doi. org/10.1016/j.nimb.2011.08.071.

25. S. Swaminathan and M. Spiegel: Surf. Interface Anal., 2008, vol. 40, pp. 268-72, https://doi.org/10.1002/sia.2732.

26. M.C. Biesinger, B.P. Payne, A.P. Grosvenor, L.W.M. Lau, A.R. Gerson, and R.S.C. Smart: Appl. Surf. Sci., 2011, vol. 257, pp. 2717-30, https://doi.org/10.1016/j.apsusc.2010.10.051.

27. T.D. Nguyen, J. Zhang, and D.J. Young: Oxid. Met., 2014, vol. 81, pp. 549-74, https://doi.org/10.1007/s11085-013-9467-y.

28. M. Polak and B. Schiffmann: J. Vac. Sci. Technol. A, 1987, vol. 5, pp. 590-92, https://doi.org/10.1116/1.574679.

29. X. Tian, R.K.Y. Fu, L. Wang, and P.K. Chu: Mater. Sci. Eng. A, 2001, vol. 316, pp. 200-204, https://doi.org/10.1016/S09215093(01)01245-X.

30. M. Godec, D. Mandrino, B. Šuštaršič, and M. Jenko: Surf. Interface Anal., 2002, vol. 34, pp. 346-51, https://doi.org/10.1002/ sia.1314.

31. J. Moon, S. Kim, W.D. Park, T.Y. Kim, S.W. McAlpine, M.P. Short, J.H. Kim, and C.B. Bahn: J. Nucl., 2019, vol. 513, pp. 297-308, https://doi.org/10.1016/j.jnucmat.2018.10.010.

Publisher's Note Springer Nature remains neutral with regard to jurisdictional claims in published maps and institutional affiliations. 